\title{
Conekões entre filosofia e ciências no séc. KIX: um estudo sobre o desenvolvimento das ciências naturais e suas reverberações na filosofia alemã deste período
}

\author{
Conections between philosophy and science in 19th \\ century: a study about the development of natural sciences \\ and its reveberentions in German philosophy
}

Profa $^{\mathrm{a}}$. Dra.

Rebeca Furtado

Colégio Pedro II

rebecafurtado7@gmail.com

Recebido em 10/09/16

Aceito em 27/10/16

Para citar este artigo: FURTADO, Rebeca. Conexões entre filosofia e ciências no séc. XIX: um estudo sobre o desenvolvimento das ciências naturais e suas reverberações na filosofia alemã deste período. Em Construção. ano 1, n. 1, 2017, pp. 25-50. DOI:10.12957/ emconstrucao.2017.28123

\section{Resumo}

Este artigo pretende apresentar, em linhas gerais, um panorama histórico da filosofia alemã do séc. XIX. Deseja-se problematizar como a consolidação tardia das ciências naturais neste país permitiu um diálogo mais profícuo entre filosofia e ciências. O trabalho discute como na segunda metade do séc. XIX o pensamento alemão realiza um retorno à filosofia kantiana, levado a cabo por cientistas e filósofos, como tentativa de superar uma crise de legitimidade que ameaçava não apenas a filosofia, mas também as ciências humanas e naturais. Na terceira parte do trabalho se debate, de maneira mais detida, o caso da filosofia de Nietzsche, a fim de resgatar e discutir a influência de Kant para o pensamento de tal autor, problematizando a relação de sua filosofia com o pensamento de Lange.

Palavras-chave: filosofia alemã; retorno a Kant; filosofia; ciências humanas; ciências naturais.

\section{Abstract}

This paper aims to present a initial historic overview of German philosophy in $19^{\text {th }}$ century. It pretends to question about the late consolidation of natural sciences and how it alowed a profitable dialogue between philosophy and sciences. It discusses the "back to Kant" movement in the late $19^{\text {th }}$ century of German thought, carried out by scientists and philosophers. This return attempts to overcome the crises of legitimacy that threatened the philosophy and human and natural sciences. In the third part, it debates the Nietzsche's thoughts case aiming to rescue and to discuss the Kant influence to his thought, in dialogue with Lange's thought.

Key words: German philosophy; back to Kant; philosophy; human sciences; natural sciences. 


\section{Apresentação}

Este artigo pretende servir como uma introdução à reconstrução histórica do desenvolvimento das ciências naturais no séc. XIX e sua repercussão para a filosofia, especialmente no cenário alemão. A ideia é problematizar até que ponto movimentos filosóficos como as escolas neokantianas de Marburg e de Baden e a filosofia de autores importantes do período como Marx, Dilthey, Husserl, Nietzsche e, posteriormente, mesmo Heidegger, não podem ser completamente separados do contexto histórico e dos impasses que o desenvolvimento das ciências, sobretudo, as chamadas naturais ou exatas, trouxeram para o escopo e tarefa da filosofia. Neste sentido, pretende-se acompanhar as transformações ocorridas neste período na maneira de compreender no que consiste o conhecimento nas Universidades e autores alemães. Além disso, como ficará mais claro no decorrer do texto, deseja-se evidenciar a importância que a filosofia kantiana assumiu, especialmente, na segunda metade do século XIX, não apenas para os impasses enfrentados pela filosofia, mas também àqueles que se impuseram às ciências naturais e às ciências humanas.

Obviamente, este trabalho, devido a sua proposta e extensão, não almeja, nem poderia esgotar tal tema, incluindo consistentemente todos os movimentos de pensamento ou autores deste período da Alemanha ${ }^{1}$. Ele não almeja tampouco discutir a relação entre ciências e filosofia ou a repercussão de uma sobre a outra em toda a sua amplitude ou com rigor conceitual de um comentário especializado sobre a filosofia dos autores que cita. Ao contrário, esse texto pretende, de maneira muito modesta, apresentar um panorama, uma visão geral sobre o tema, a fim de situar o leitor não especializado no tema, permitindo e convidando cada leitor a se interessar por essas questões e buscar fontes adicionais, de acordo com seus interesses.

Esse trabalho está dividido em três partes. A primeira apresenta uma breve reconstrução histórica do cenário do século XIX em relação ao desenvolvimento e consolidação das chamadas ciências naturais, como paradigma de conhecimento moderno. A segunda parte problematiza a crise da mecânica clássica e suas consequências para a legimitidade do conhecimento das ciências. Assim como apresenta a estratégia de retorno a Kant, para discutir a tarefa e os limites do conhecimento, trazendo à tona uma relação muito próxima entre filosofia e ciências. Por fim, a terceira, discute o caso da filosofia nietzschiana como um exemplo deste retorno à filosofia kantiana, por meio de um debate com um (proto) neo-kantiano do período, Albert Lange, que apesar de ter sido um pouco esquecido pela tradição, desempenhou um papel relevante nesta discussão levada a cabo na Alemanha, no referido período.

Comecemos, pois, do início...

\section{Breve histórico sobre o desenvolvimento das ciências naturais no século KIK}

O século XIX foi, sem dúvidas, um século decisivo para o desenvolvimento das ciências (MERZ, 1907, p. 89). Não apenas pelo crescimento e consolidação de métodos, instituições, da forma e das características que, de certa forma, ainda hoje reconhecemos como científicas, mas ainda por esse processo ter culminado no questionamento de suas bases e ter marcado o início do movimento de plurificação das ciências, levado a cabo no início do século seguinte (VIDEIRA, 2012, p. 13).

O termo ciência já no final do séc. XIX possuía um sentido popular bastante usual e compreensível apesar de diferenças notáveis entre os significados das palavras inglesa (science), francesa (science) e, sobretudo, alemã (Wissenschaft). John Theodore Merz (1840 -1922), um historiador do período, que será usado aqui como importante fonte bibliográfica para tal reconstrução histórica, sugere que, na língua inglesa, a palavra 'science' adquiriu seu significado juntamente com a formação de instituições como, por exemplo, a British Association for the Advancement of Science (1831). O autor ressalta que o que usualmente se denominava science nesse momento, não raramente era ainda substituído pelo termo filosofia ou mais especificamente filosofia natural, por herança de seu uso comum nos séculos anteriores. Em contrapartida, na França os dois

1 Uma lacuna evidente do trabalho, por exemplo, é não mencionar o pensamento do matemático e filósofo Friedrich Ludwig Gottlob Frege (1848 -1925) ou discutir sua importância para a posterior consolidação da filosofia analítica. 
termos já não eram utilizados como sinônimo (MERZ, 1907, p. 90, nota 1). A palavra 'science' possuía uma aplicação ampla, englobando campos diversos do conhecimento, mas assumia um sentido mais estrito, quando adjetivada como "exata" ou "natural" (assim como a língua inglesa delimitava o termo filosofia através dos adjetivos "natural" ou "experimental"). De qualquer forma, em inglês, o termo 'philosophy' herança, sobretudo, da escola baconiana foi cada vez mais abandonado em prol do 'science', em certa medida pela influência do uso francês e sua distinção radical entre os vocábulos, contudo, de maneira ainda mais decisiva, na busca de marcar radicalmente a diferença e distância do tipo de conhecimento gerado pelas ciências em relação ao conhecimento metafísico filosófico.

Outra distinção importante entre o significado dos termos nestes dois países se deu pelo próprio acento dado à caracterização da investigação científica. A palavra 'science' inglesa comumente esteve mais associada à experiência e à observação, enquanto, na França a prática científica manteve-se mais próxima à matemática (MERZ, 1907, p, 90). Por sua vez, a palavra alemã 'Wissenschaft' possui um significado muito mais amplo que o significado de ciência no sentido moderno presente na tradução dos verbetes em inglês, francês ou mesmo na palavra 'scientia' do latim. Ainda de acordo com Merz, a ideia mais compatível com o significado nos outros idiomas seria encontrada nos termos 'exacte Wissenchaft' que englobaria tanto a 'mathematik' (matemática) quanto a 'Naturwissenschaft' (ciência da natureza) (MERZ, 1907, p, 90). Pretendemos voltar à caracterização do conceito expresso por Naturwissenschaft e de sua importância para o pensamento e cultura alemã, quando tratarmos, mais adiante, das universidades alemães.

Contudo, apesar de mesmo antes do início do séc. XVII já identificarmos transformações fundamentais no pensamento para o surgimento da ciência moderna ${ }^{2}$, como as que encontramos nas obras de autores como Galileu Galilei (1564-1642), René Descartes (1596-1650), Francis Bacon (1561-1626), Johannes Kepler (1571-1630), Isaac Newton (1643-1727), entre outros, poderíamos considerar que a institucionalização e, consequentemente, a realização dos projetos e programas da ciência moderna começam a se consolidar de maneira mais significativa na segunda metade do século XVIII, inicialmente nas academias francesas (MERZ, 1907, p. 95). E isso porque, apesar de já estar manifesta, nesses autores "pioneiros", a necessidade de regras e métodos específicos, assim como, a limitação dos objetos e campos da investigação da filosofia natural, que caracterizarão, em grande medida, a preocupação do "espírito moderno", é apenas mais tarde que o ideal de cooperação coletiva, em prol do trabalho científico organizado, poderá se concretizar. Cassirer chama atenção para o fato que algumas formulações que dão todo o mérito e ênfase para a modernidade, no que diz respeito à formulação do ideal científico, passam a falsa impressão de que ela não seja fruto do desenvolvimento histórico de reflexões acerca do conhecimento, que desde seus primórdios estiveram marcadas pela preocupação com o método e os limites da ciência (CASSIRER, 1953, p. 131). Além disso, as transformações sociais, culturais e mesmo econômicas a partir das ciências foram mais efetivas nesse segundo momento, na medida em que o impacto do aumento das pesquisas e invenções científicas e tecnológicas, conjugado com a promoção do conhecimento, se refletiu diretamente na vida prática, por meio da abertura de possibilidades para a indústria, para o comércio e para o mercado de trabalho, transformando consideravelmente a vida prática no séc. XIX (MERZ, 1907, p. 92). Merz defende que a França do séc. XVIII possuía condições favoráveis para a consolidação de tal institucionalização das ciências e, foi tal institucionalização justamente que possibilitou o desenvolvimento pioneiro das ciências nesse país. Contudo, até o final do século seguinte, o ideal da ciência moderna já havia se expandido por toda Europa. Nas palavras do historiador, encontramos o seguinte: "Ao fim de nosso século, ou melhor, ainda durante a sua segunda metade como um todo - nós encontramos esse espírito da naturalização na Itália, na Alemanha, na Inglaterra, no norte e leste da Europa. Já não há agora uma ciência que possa ser considerada preeminentemente de uma nação." (MERZ, 1907, p. 156)3.

Já em 1792, Nicolas de Condorcet (1743 - 1794), um matemático e cientista político francês que desempenhou um papel fundamental na consolidação do modelo científico iluminista de educação na França, envia

2 Poderíamos citar, como exemplo, a importância de obras como De revolutionibus orbium coelestium (1543) de Copérnico (14731543).

3 As citações que aparecerem no corpo do texto são traduções livres minhas, as que aparecem em nota de rodapé foram mantidas no idioma original. 
à Assembleia Nacional Francesa, em nome do "Comitê de Instrução Pública", um documento defendendo um sistema de ensino público, intitulado como "Relatório e Projeto de Decreto sobre a Organização Geral da Instrução Pública"4, que parece bastante relevante, por condensar uma série de pressupostos da crença na superioridade do conhecimento científico em relação ao conhecimento especulativo filosófico, que serviram como base desta ampla difusão por toda a Europa. No documento, ele defende:

Muitos motivos podem ser dados para a preferência em relação às ciências matemáticas e
físicas. Primeiramente, para homens que não devotam sua vida às longas meditações, que
não se aprofundam em nenhum tipo de conhecimento - mesmo o estudo elementar des-
sas ciências, é a maneira mais correta de desenvolver suas faculdades intelectuais, de en-
siná-los a pensar corretamente e analisar suas ideias (....) Isto se deve ao fato das ciências
naturais serem mais simples, mais rigorosamente circunscritas, isto é, porque sua lingua-
gem é mais perfeita, (...) Essas ciências oferecem um remédio ao preconceito, à pequenez
da mente - um remédio, que se não garantido, é, pelo menos, o mais universal, mais que a
filosofia em si. (...) A literatura tem seus limites, a ciência da observação e cálculo, não. O
gosto por ocupações literárias, quando não se possui um certo grau de talento, produz ou
um orgulho ridículo ou um ressentimento pela ausência de tais talentos que não podem
ser obtidos. Nas ciências, ao contrário, não é a opinião de um homem, mas a natureza
com o que se deve engajar uma disputa, cujo triunfo é quase sempre garantido, na medida
em que cada vitória predita uma nova. (apud HIPPEAU ${ }^{5}$, in: MERZ, 1907, p. 110 e 111).

Essa passagem é importante não apenas por evidenciar o ideal a partir do qual as instituições modernas francesas de ensino foram criadas, ou pelo papel central ocupado pela ciência nesse programa educativo, mas também por trazer à tona uma série de pressupostos a partir dos quais o ideal científico se baseou e fundamentou. Poderíamos, de início, destacar a menção à idealização dos fenômenos a partir da linguagem matemática. A definição de Condorcet de que a ciência possui maior simplicidade e rigor deve-se, em grande parte, à possibilidade de quantificação e mensurabilidade dos fenômenos, que garantiriam assim, formulações mais diretas e exatas, assegurando supostamente maior universalidade ao conhecimento. Essa progressiva matematização ocorreu, sobretudo, na França, a partir dos estudos sobre o pensamento de Newton tendo em vista a eliminação da arbitrariedade dos fenômenos específicos, e a redução das possibilidades de medições equivocadas provenientes de erros humanos. A conjugação entre matemática e empirismo foi, sem dúvida, um acontecimento decisivo para a consolidação da forma da ciência moderna e desenvolvimento de suas possibilidades (MERZ, 1907, p. 109 - 121). O fato de a linguagem matemática garantir maior exatidão e invariabilidade das relações estabelecidas entre seus símbolos contrapuseram as sentenças das teorias científicas aos conceitos flutuantes e inexatos com que a filosofia tradicional, entendida como metafísica, tentava expressar suas doutrinas. Daí a afirmação de Condorcet de que a ciência produz um conhecimento mais simples e universal que a filosofia.

Da mesma maneira, a idealização dos fenômenos, por meio da linguagem matemática, pretendia ainda estabelecer uma distância entre o que é conhecido e aquele que conhece. O conhecimento científico pretende ser universalmente válido e, nesse sentido, as características da relação particular entre o cientista

4 Para mais informações sobre a importância de Condorcet para a política francesa, sua influência no estabelecimento da educação pública, pós Revolução Francesa e seu legado em relação às bases doutrinarias da defesa da educação gratuita, universal e laica, ver RODRIGUEZ, M. V. A origem da escola moderna: o legado de Condorcet. In: Acta Scientiarum, Education, vol. 32, n. 1, pág. 67 a 74, Maringá, 2010.

5 Célestin Hippeau (1803-1883), importante teórico da educação da França no séc. XIX. Edita, a partir de 1870, uma série de volumes sobre educação comparada, isso é, sobre o ensino em diversos países, seus métodos e instituições, buscando uma espécie de integração entre os sistemas educacionais. Seus escritos tinham como objetivo tanto promover na França debates sobre organizações e sistemas de instrução de outros países, como divulgar o modelo francês e seus ideais de educação pública, laica, gratuita e universal nos demais países. Seus relatórios sobre educação comparada tiveram uma influência considerável sobre a organização da escolarização no Brasil, no final do séc. XIX. Cf. BASTOS, Maria Helena Câmara. A educação comparada no século XIX: A obra de Célestin Hippeau. O trecho apresentado é de autoria de Condorcet, mas documentado e narrado por Hippeau. 
e o fenômeno que ele estuda não devem ser levadas em conta. Ao contrário, qualquer descoberta apenas possui relevância científica quando possui aplicação irrestrita, isto é, é válida para qualquer tempo e lugar. A linguagem científica deveria buscar se expressar sempre da maneira mais simples e exata, a fim de possibilitar que, em tese, qualquer um, a qualquer momento, pudesse reconstruir seus passos e repetir suas experiências, obtendo as mesmas conclusões e resultados. Conjugado a tal matematização, o desenvolvimento de técnicas e instrumentos de experimentação cada vez mais precisos possibilitaria a reprodução e assimilação deste tipo de conhecimento sem ressalvas ou dependências de habilidades específicas. As teorias devem apresentar-se de tal maneira que a simplicidade de sua estruturação não requeira um acesso privilegiado ou um talento especial, mas, ao contrário, seja por princípio, universalizável. Em outras palavras, elas devem ser reprodutíveis por qualquer um, em qualquer lugar e tempo, desde que se sigam as condições internas do experimento, que supostamente são guiadas pelas próprias necessidades do objeto estudo e não pelo sujeito específico que desenvolve a pesquisa. A possibilidade de experimentação ou repetição intersubjetiva, portanto, baseia-se ainda em outro pressuposto não verbalizado, a saber: de que, em princípio, todos os homens possuem a mesma capacidade cognitiva para conhecer os fenômenos naturais. Não há qualquer requisito ou acesso exclusivo de nenhuma ordem, seja de iniciação mística ou tendências de caráter, personalidade ou gosto.

Essa característica não é de pouca monta na medida em que marca uma diferença fundamental com o pensamento filosófico. Se por um lado é certo que na filosofia há formação de tradições e escolas e nesse sentido, há uma relação interna de ideias que perpassa e ultrapassa os próprios autores, por outro, não é possível pensá-las de uma maneira completamente despersonificadas, ou autonomizadas de seus autores: na filosofia o aspecto especulativo autoral é insuperável. Herbert Schnädelbach ratifica essa característica ao discutir o vocábulo ciência em seu livro de reconstrução histórica da filosofia na Alemanha desse período. Ele segue a sugestão de Helmuth Plessner de que, em consonância com o processo produtivo pós-revolução industrial, a estrutura interna da ciência e a estrutura da personalidade do cientista são completamente transformadas. Plessner descreve como principais características comuns a esses dois processos, o desenvolvimento industrial e o científico, a "mecanização, sistematização e despersonalização" da produção (SCHNÄDELBACH, 1991, p. 91). Nesse sentido, o cientista, enquanto pessoa e indivíduo específico, é completamente substituível e irrelevante, pois nada em sua personalidade deve ser decisivo ou influenciar na investigação que ele realiza. Desta maneira, ocorre uma espécie de autonomização do processo de investigação em relação ao próprio cientista, na medida em que todos os resultados e continuidade da pesquisa devem ser completamente independentes do sujeito.

No final da passagem acima citada, há mais uma pressuposição importante para o ideal científico que gostaríamos de ressaltar. Tal pressuposto consiste justamente na consideração de que a objetividade da ciência provém, em sintonia com o que dissemos acima, do fato das teorias não serem forjadas a partir da capacidade do sujeito, mas, ao contrário, pretenderem dar voz à própria natureza, por meio de descrições dos fenômenos naturais, tais como eles se apresentam (CASSIRER. 1953, p. 113). Isso significaria aceitar que o papel do cientista é somente descobrir leis que regem os próprios fenômenos. O conhecimento é independente de quem conhece porque a natureza mesma é independente do sujeito, ela não foi criada por nós e, nesse sentido, cabe ao cientista apenas desvendar e formular as leis a partir da linguagem científica, pois elas já estão disponíveis na própria natureza. A célebre passagem de Galileu poderia ser uma boa ilustração dessa pretensão de objetividade, a partir das duas características que ressaltamos, a necessidade da idealização matemática dos fenômenos e do realismo que defende que as leis naturais já estão na natureza:

A filosofia encontra-se escrita neste grande livro que continuamente se abre perante nossos olhos (isto é, o universo), que não se pode compreender antes de entender a língua e conhecer os caracteres com os quais está escrito. Ele está escrito em língua matemática, os caracteres são triângulos, circunferências e outras figuras geométricas, sem cujos meios é impossível entender humanamente as palavras; sem eles nós vagamos perdidos dentro de um obscuro labirinto (GALILEU, 1978, p. 119). 
Tal concepção realista pretende se afastar de qualquer especulação de cunho metafísico, marcada pela impossibilidade de observação e cálculo, restringindo-se a uma metodologia própria que tolere apenas descobertas de leis demonstráveis. O desenvolvimento desses métodos, portanto, precisa pretensamente submeter-se apenas às necessidades do objeto a ser conhecido, isto é, o real (a natureza) possui características específicas que precisam ser levadas em conta para sua observação adequada. A ciência deve manter-se autônoma, seguindo somente as determinações e escolhas metodológicas que a própria natureza lhe obrigue a trilhar, sem interferências de interesses ou especificidades alheias de qualquer ordem. Além disso, a ciência deve abrir mão completamente de objetivos inalcançáveis como os da metafísica, que se perde em especulações nas quais seus objetos, em última instância, nunca são experimentáveis ou comprováveis objetivamente. Por essa razão, o objetivo da ciência moderna já não diz respeito a causas últimas ou princípios e razões primeiras, consistindo senão na descrição dos fenômenos naturais em suas relações. Como vimos, essa característica é ilustrada de maneira clara pela obra de Comte (COMTE, 1978, p. 54), mas diz respeito ao novo ideal de conhecimento científico moderno como um todo. Como formula Cassirer na seguinte passagem:

Em oposição ao ideal metafísico de explanação da natureza, agora surge a mais modesta tarefa de descrever o real completa e claramente. Nós não vamos mais além do campo do sensível a fim de descobrir o não experienciável, causas e forças absolutas. Sobre o que assenta a multiplicidade é, ao contrário, constituído meramente pelos fenômenos na forma em que eles são imediatamente acessíveis por nós (CASSIRER, 1953, p. 114).

Por último, há, de maneira implícita, ainda outro aspecto importante na noção moderna de ciência expressa na fala de Condorcet que também se encontra em perfeita consonância com os dois precedentes. Trata-se da ideia expressa na última frase da passagem, na qual ele sugere que cada conquista científica prevê uma nova. Poderíamos ver nessa afirmação uma referência ao caráter coletivo do trabalho científico, assim como, à importância de que seus resultados sejam públicos. Se cada descoberta e conquista investigativa antecipa, abre as portas para novas descobertas, então, primeiramente é desejável que tais descobertas sejam maximamente sistematizadas, concentradas e divulgadas a fim de potencializar as oportunidades de surgimento de novas conquistas. Além disso, de alguma maneira, a relação entre uma descoberta e a antecipação de uma próxima revela uma espécie de dependência que une as conquistas em um processo cumulativo, na medida em que cada descoberta é debitária de alguma forma de conquistas anteriores. Contudo, se a dinâmica científica se realiza através de processos cumulativos de produção do conhecimento, podemos afirmar que essa construção possui um caráter coletivo na medida em que um indivíduo não dá conta de toda a tarefa, mas, ao contrário, o conhecimento é construído e sistematizado coletivamente a partir de bases já conquistadas anteriormente, que abrem as possibilidades no futuro. Tal característica se harmoniza, novamente, com a pretensão de universalidade e objetividade como repetição interpessoal, tal qual comentamos anteriormente.

Schnädelbach denomina tal aspecto como "dinamização da ciência" e afirma que ela está completamente atrelada à ideia de despersonalização da investigação, de universalização e de acúmulo dos resultados. Essa processualidade autônoma em relação a um cientista individual é muito bem descrita por ele, da seguinte maneira: "Uma ciência obrigada a investigar continuamente para renovar a indústria e renovar-se a si mesma já não se identifica por seu conteúdo (irremediavelmente condenado a ser superado), mas por seus métodos e procedimentos, e se converte em uma ciência - investigação" (SCHNÄDELBACH, 1991, p. 92). Isto quer dizer que tal dinamização transforma completamente a estrutura do ideal de conhecimento, abrindo caminhos para a especialização e internacionalização da ciência, que se realizam a partir da manutenção do processo investigativo-produtivo. O método e a educação dentro desses procedimentos assumem a primazia frente a qualquer conquista de conteúdo, e por isso os próprios resultados específicos passam a ser menos importantes que a continuidade do assegurada da dinâmica de pesquisa.

A partir dessas considerações, poderíamos resumidamente enumerar os pressupostos e características que assinalam o ideal científico que se consolida no séc. XIX: universalidade, objetividade, realismo, autonomia da natureza, possibilidade de reprodução, além do caráter coletivo, cumulativo e público da produção 
de conhecimento (VIDEIRA, 2011, 194). Contudo, não podemos perder de vista o que tais características buscam legitimar. Tal tipo de conhecimento surge com tantas prerrogativas a fim de garantir a segurança e a certeza no estabelecimento de seus enunciados. Por isso, adjetivações como ciência exata, leis demonstráveis, conhecimento experimentável e matemático são tão fundamentais. Contra toda especulação supostamente vazia e incerta da tradição metafísica, o conhecimento científico surge se propondo a formular leis e teorias de tal maneira que seus enunciados sejam demonstrados tanto empírica, quanto matematicamente, garantindo, assim, a exatidão e a certeza desse conhecimento (CUVIER apud MERZ, 1907, p. 154).

Diante deste panorama, nos interessa agora, acompanhar de maneira mais específica, como se deu tal desenvolvimento na Alemanha, na medida em que os autores que comentaremos aqui pertencem a tradições filosóficas alemãs dessa época e, assim, poderemos ter em vista, mais claramente, o cenário intelectual a partir do qual eles falam.

Ainda segundo Merz, poderíamos considerar que a Alemanha não forneceu grande aporte para a consolidação das ciências modernas antes e no início do século XIX. Porém, de maneira especial, foi responsável pelo desenvolvimento das bases do sistema universitário contemporâneo. Merz sugere que uma transformação importante que ocorreu a partir de 1737, com a fundação da Universidade de Göttingen, foi a introdução da "libertas docendi" no programa universitário. Tal mudança representou uma nova relação com o ensino, na medida em que anteriormente as faculdades de teologia, direito (leis) e medicina conduziam seus estudos de acordo com finalidades práticas, muitas vezes tendo em vista interesses do Estado e da Igreja. Inspirada na faculdade de filosofia, que já apresentava o ideal de conhecimento autônomo, a introdução da libertas docendi na Universidade pode ser considerada a pedra fundamental da constituição acadêmica (MERZ, 1907, p. 164).

O sistema universitário alemão não estava destinado, contudo, apenas ao ensino e reprodução do conhecimento, mas visava, sobretudo, à pesquisa ${ }^{6}$. A palavra 'Wissenschaft' sintetiza o desenvolvimento de um ideal de conhecimento que surgiu com as universidades alemãs e que está diretamente ligada a essas características. 'Wissenschaft', geralmente traduzido por ciência, como dissemos anteriormente, não corresponde nem ao significado de 'science' inglês, nem francês, tampouco em português, nem pode ser traduzido por nenhuma outra palavra única nesses idiomas, sendo uma palavra que necessita ser qualificada em sua especificidade. A distinção entre filosofia e ciência, como conhecimento exato, experimental e matematizado, que tentamos reconstruir no início deste texto, a partir dos comentários de Merz, não pode ser aplicada na simples tradução de 'Wissenschaft' por ciência. Tal palavra alemã não possui em si uma noção de contraposição necessária à palavra filosofia. A palavra que melhor se adequa a tradução por ciência, tal como a definimos acima, seria o composto 'mathematisch- naturwissenschaft'.

'Wissenschaft', ao contrário, engloba o ideal (mais amplo) do tratamento universitário do conhecimento, podendo aplicar-se, por exemplo, a áreas como teologia, jurisprudência, medicina e a estudos filosóficos, quando tratados "cientificamente", isto é, como define Merz, visando uma forma sistemática e unificada do conhecimento humano ${ }^{7}$. Tal objetivo se afina completamente com a proposta universitária de abarcar várias ramificações do conhecimento, sob um mesmo espaço e sistema, em contato contínuo e pertencendo a um todo organizado. Essa concepção mais abrangente de ciência não assumia que apenas o método das ciências naturais fosse adequado para garantir o status de conhecimento científico, na medida em que haviam diversos métodos considerados científicos, de acordo com os distintos ramos da ciência:

6 Há na Alemanha uma distinção importante entre institutos superiores, escolas técnicas e universidades, com objetivos e enfoques distintos, inclusive, há diferentes instituições desde o nível médio, ver MERZ, 1907, p. 166, em especial, nota 1.

7 Merz cita, por exemplo, a definição de Fichte (1762-1814) de Wissenschaft, no início de sua primeira obra filosófica, publica em 1794, na qual o filósofo afirma que a "Philosophy is a science", dizendo em seguida o que significa isso: "A science has a systematic form; all propositions in it hang together in one single fundamental proposition, and are united by it into a whole." Merz, na mesma nota, marca a diferença entre o significado de ciência para os franceses, nesse momento: “(...) the sciences as cultivated by the great Frenchmen had a unity of method, the exact method, the method of observation, measurement, and calculation, but not necessarily a unity of system, or a highest all-embracing proposition. It is evident that science means to Fichte something more than it meant to the Académie des Science: it means Wissenschaft, not merely methodical, but systematic, unified knowledge." (MERZ, 1907, 170, nota 1). 
Antes mesmo dos métodos das ciências exatas serem introduzidas na Alemanha sob as influências inglesa e francesa, os alemães possuíam muitos métodos científicos. Havia o método da crítica filosófica, estabelecido por Kant; a ciência da crítica histórica, da crítica bíblica; a ciência da filologia: todas essas disciplinas professavam ter tanto métodos quanto definição, objetivos, e um estilo próprio, como o que as ciências exatas trouxeram com elas. (MERZ, 1907, p. 173).

Durante o século XVIII podemos afirmar que nas universidades alemãs havia maior demanda por estudos clássicos e filosóficos, não possuindo ainda uma inserção muito grande do "espírito moderno das pesquisas naturais e exatas", que já eram amplamente desenvolvidas nas Academias francesas. Alguns expoentes alemães das ciências naturais estavam fora das universidades, ligados a outras organizações internacionais (por vezes, mesmo as francesas) e exercendo pouca influência sobre o pensamento hegemônico alemão, que ainda se mantinha de cunho especulativo filosófico.

\subsection{Reverberações entre ciências naturais e filosofia na Alemanha: a busca pelo método e o estabelecimento da filosofia como ciência}

Até o final do séc. XIX, o quadro acima apresentado já havia se alterado substancialmente. O crescimento da influência dos cientistas franceses e ingleses, que nesse momento já haviam consolidado o ideal de conhecimento exato por meio dos métodos e abordagens característicos das ciências naturais, se tornava tendência dentro das universidades alemãs.

Diante da introdução desse ideal de conhecimento, conjugado com transformações internas no cenário alemão (políticas, econômicas, mas também filosóficas), o conhecimento filosófico especulativo e metafísico começa a ser colocados em xeque de maneira radical na Alemanha especialmente a partir da década de 30. E isso porque, ao contrário da França e da Inglaterra, a maneira como o idealismo alemão se desenvolveu manteve a possibilidade do conhecimento metafísico, entendido como a busca pelos princípios universais, transcendentais ou mesmo transcendentes de todos os entes, ainda muito forte e viva até esse período. Herbert Schnädelbach, em seu já citado livro intitulado: Filosofia na Alemanha (1831-1933), chega a assumir 1831, o ano de morte de Hegel, como a data simbólica dessa transformação. Somada a saída de Schopenhaeur da Universidade no mesmo ano e a morte de Goethe em 1832, esse momento marca simbolicamente o começo de uma transformação decisiva da filosofia e da noção de conhecimento como um todo na Alemanha. Ele diz:

Até a década dos anos 30, em um sentido estritamente cultural, não havia começado o século XIX na Alemanha e, portanto, tampouco a época da ciência, da cultura histórica, do realismo, do "desencanto" e, também, do início da crise da civilização humanista europeia, cujo autêntico alcance não se revelaria até a chegada das duas guerras mundiais. (SCHNÄDELBACH, 1991, p. 13 e 14).

De maneira um tanto quanto "tardia", quando comparamos a outros países europeus, apenas a partir da década de 30, as ciências naturais e, em seguida, a plurificação das ciências humanas, começaram a dominar a cena nas universidades alemãs. Essa mudança, contudo, não foi realizada apenas como uma simples troca da filosofia pela ciência, mas, ao contrário, ela é realizada por meio de uma crise interna que se evidencia no próprio projeto filosófico. A crise, como vimos, é, sobretudo, referente à eficácia, possibilidade e relevância do pensamento metafísico. Nesse sentido, ela ocorre, em primeiro lugar, no ambiente e âmbito estritamente filosófico.

Isso pode ser visto de maneira clara pela maneira em que o próprio "hegelianismo" foi derrocado. Como Karl Löwith discute minuciosamente em seu clássico "De Hegel a Nietzsche", os neohegelianos e os jovens hegelianos (ou os denominados hegelianos de esquerda) avançam críticas que, embora se vinculassem de algum modo ao pensamento hegeliano, descaracterizavam completamente seu sistema como um todo, atacando, ainda que de modos distintos, diretamente o seu âmago, a saber: a filosofia do Absoluto. Desde o "sensualismo" de L. Feuerbach (1804 - 1872) e sua forte crítica e recusa aos elementos suprassensíveis e reli- 
giosos do sistema hegeliano, passando pelo materialismo dialético de K. Marx (1818 - 1883) e a necessidade de transformar a filosofia em prática política, ou em M. Stirner (1806 - 1856), em Bauer (1809 - 1882) e até mesmo em S. Kierkegaard (1813 - 1855) e sua ênfase na necessidade de se pensar a existência individual em oposição ao espírito absoluto hegeliano - todos esses pensadores se caracterizaram pela crítica a absolutização que os sistemas metafísicos realizavam. Tendo especialmente como referente o pensamento hegeliano, o problema consistia no fato de que a metafísica impedia o autêntico e necessário pensar a realidade em sua concretude histórica, seu aspecto fático, sensível e mesmo material (LÖWITH, 2012, pp. 79 - 184).

Uma afirmação da exposição histórico-crítica da filosofia de Hegel realizada por R. Haym (1821-1901) revela a atmosfera de transformação radical desse momento. Aí Haym não apenas evidencia a decadência do sistema hegeliano enquanto tal, mas discute como essa crise afeta a própria filosofia em geral:

Esta grande casa de comércio faliu, porque toda sua especialidade está prostrada. (...) Nos encontramos, no momento, em um grande e quase universal naufrágio do espírito e da fé no espírito em geral. (...) Esta já não é uma época de sistemas, já não é uma época para a poesia ou a filosofia. Ao contrário, trata-se de um tempo em que, graças às grandes invenções técnicas do século, a matéria parece ter se tornado viva. Os mais profundos fundamentos de nossa vida física e de nossa vida espiritual foram demolidos e recriados pelo atual triunfo da técnica. A existência dos indivíduos, juntamente com a dos povos, foi levada a novas bases e relações. (HAYM apud LÖWITH, 2012, p. 88)

O declínio definitivo dos grandes sistemas metafísicos, simbolizado pela morte de Hegel, abriu caminho para a consolidação das ciências naturais que até então ainda não havia ocorrido na Alemanha. Durante a época em que Hegel esteve lecionando, a universidade alemã estava formada por quatro faculdades: filosofia, teologia, medicina e direito. É sintomático que apenas na década de 1860 a faculdade de ciências naturais tenha se separado da de filosofia na Alemanha (SCHNÄDELBACH, 1991, p. 95), enquanto que nos outros países europeus, elas já possuíam bastante estabilidade institucional. Essa consolidação, por sua vez, traz um novo paradigma de conhecimento, a saber: o conhecimento que precisa se certificar de seu objeto enquanto o "efetivamente real", enquanto fenômeno experimentável empiricamente. O pensamento filosófico se viu, dessa maneira, diante da necessidade de questionar sua legitimidade frente a esse novo modelo de conhecimento instaurado pelas ciências naturais. A filosofia precisou se reestruturar e passou a querer se afirmar, cada vez mais, como uma ciência. Para tanto, precisou rejeitar e abrir mão de qualquer projeto sistemático e totalizante de pensar o ser dos entes em geral, restringindo-se a aspectos específicos dos fenômenos humanos. A tendência geral, portanto, foi de limitar seu escopo de maneira científica. A filosofia então se entendeu ou bem como "história da filosofia" (LÖWITH, 2012, p. 89-93), limitando seu exercício à tarefa interpretativa de compreender os diversos sistemas filosóficos como "visões de mundo", ou tentou procurar outras maneiras de se posicionar e fundamentar como uma ciência específica: como psicologia, filologia, história etc. Cada uma dessas tentativas, contudo, por mais que se mostrassem promissores campos de investigação, evidenciavam a derrocada da filosofia em um sentido forte, isto é, entendida como metafísica clássica.

Contudo, a ideia de método científico matemático e empírico não pode ser simplesmente transposta para o estudo dos fenômenos humanos na medida em que estes não se adequam à maneira com que as ciências naturais lidam com seu objeto de estudo, isto é, os fenômenos naturais. Nesse momento, ainda havia de maneira sedimentada (apesar disso também ser questionado por alguns cientistas e filósofos) a crença de que existia uma diferença fundamental entre as ciências naturais e humanas, na medida em que as segundas possuíam um caráter interpretativo teórico, o qual as primeiras prescindiriam, dado à objetividade e exatidão obtida por meio da experiência. Esse resquício de positivismo, a saber, a ideia de que as ciências naturais apresentam maior grau de precisão por seu caráter empírico, por serem submetidas a experimentos e observações objetivas, coloca a filosofia e as ciências humanas em uma situação desconfortável. Enquanto conhecimento que tem pretensão de ser válido, elas precisam se mostrar como ciências tão "seguras" 
quanto às "exatas". Esse problema gera a necessidade de que as ciências humanas sejam capazes de elaborar um método específico coerente e adequado aos seus objetos.

Isso significa que a passagem da concepção do ideal de conhecimento da filosofia à ciência marca a dificuldade e o desafio de estabelecer bases metodológicas suficientemente sólidas capazes de ancorar a legitimidade do conhecimento sobre os fenômenos humanos (DILTHEY, 2000, p. 89). Encontrar, construir, estabelecer tais fundamentos foi o desafio de diversos pensadores nesse momento, que se prolongou, pelo menos, até as primeiras décadas do século XX. Apesar da crise no modelo positivista dentro das próprias ciências naturais (em especial da física, como comentaremos em seguida), que instaurou uma complexificação da questão sobre a legitimidade do conhecimento, a ideia da importância do método para produzir conhecimento válido se impôs como paradigma para a filosofia e para as ciências humanas. A segunda parte desse trabalho apresentará uma breve discussão sobre a crise na mecânica clássica e as consequências dessa crise para o ideal de conhecimento, para o qual mesmo a noção positivista de descrição pura dos fenômenos já não será viável.

O elogio ao método já estava presente, mesmo antes do positivismo, pelo menos desde Descartes como o desenvolvimento de um procedimento assegurador do objeto de investigação e dos resultados da mesma e, nesse sentido, essa noção se confunde com o início da modernidade ${ }^{8}$. Contudo, frente aos rápidos avanços e resultados das ciências naturais, a filosofia e as ciências humanas se viram confrontadas e pressionadas a desenvolver um método tão eficaz quanto o das ciências naturais. Esse período foi, portanto, marcado pela busca da consolidação das ciências humanas através da elaboração e sistematização de seus métodos.

\subsection{Filosofia e método científico: um balanço geral do paradigma científico no pensamento filosófico alemão do final do século KIK a meados do século KK}

Nesse cenário de grandes transformações no paradigma da noção de conhecimento, encontramos muitos autores que se dedicaram a questionar e buscar uma forma de fundamentar a filosofia como uma ciência humana. Certamente, entre eles, podemos destacar Dilthey e seu esforço por estabelecer as bases para as ciências humanas a partir de sua especificidade. Mas também é mister reconhecer que a preocupação de Husserl, em estabelecer a fenomenologia como ciência rigorosa, ainda está vinculada a essa tarefa. O lema fenomenológico "rumo às coisas mesmas" e a centralidade das noções de evidência e descrição fenomenológica certamente estão atreladas à necessidade de reconquistar a legitimidade do conhecimento produzido pela "nova filosofia científica", em oposição aos sistemas metafísicos, considerados vazios, irrelevantes ou, no mínimo, insatisfatórios. Desta maneira, mesmo autores como Husserl, que insistiam no caráter transcendental da filosofia, em oposição ao psicologismo da época, ainda estavam em busca de um método que pudesse garantir a cientificidade do conhecimento filosófico.

Poderíamos citar ainda, Heidegger, que desde o início se manteve estritamente interessado na questão sobre o ser, (e, portanto, em ontologia, um 'campo de estudo', sem dúvida, filosófico no sentido forte da palavra), pois em seus primeiros escritos e cursos, ainda manteve essa preocupação sobre a necessidade de assegurar o conhecimento produzido pela filosofia, afirmando-a como uma ciência. Os cursos dos anos 20 apresentam uma série de formulações que evidenciam essa tendência. Em Ontologia: hermenêutica da facticidade, por exemplo, um curso de 1923, Heidegger usa formulações como "filosofia científica, objetiva" e "universal e concreta" para qualificar a ontologia levada a cabo por meio da fenomenologia em oposição às "arbitrariedades acríticas da filosofia das concepções de mundo" (HEIDEGGER, 2012, p. 69).

É inegável que, desde o início do pensamento heideggeriano, exista uma diferenciação fundamental entre ciência e filosofia. Todo o esforço realizado em Ser e tempo, por exemplo, em diferenciar a ontologia

8 Heidegger destaca exatamente esse aspecto ao afirmar que na modernidade a concepção de verdade se dá como certeza e autoasseguramento através do método. Ver sobre isso, especialmente, Nietzsche II: "O verdadeiro é apenas o assegurado, o certo. Verdade é certeza, e para essa certeza permanece decisivo o fato de nela o homem estar cada vez certo e seguro de si mesmo. Por isso, para o asseguramento da verdade enquanto certeza em um sentido essencial, o pro-cedimento e o asseguramento-de-antemão são necessários. (...) 'Método' é agora o nome para o pro-cedimento assegurador e conquistador que se abate sobre o ente, a fim de assegurá-lo como objeto para o sujeito”. (HEIDEGGER, 2007, p. 126 e 127). 
fundamental e as ontologias regionais provém desta diferença. Isto é, tal como Heidegger mostra nesta obra, as ciências ônticas já pressupõem ontologias regionais que estabilizam e fundamentam os "conceitos fundamentais" dos entes em questão em seu campo de estudo, a fim de que eles se tornem disponíveis positivamente para a pesquisa científica. O objetivo de Ser e tempo, pensado como a tarefa primordial que a filosofia nunca levou a cabo propriamente, vai, portanto, muito além do esforço de fundamentação de ciências particulares: ele consiste em elaborar uma ontologia fundamental. Isso significa dizer que, o objetivo da obra é colocar propriamente a questão sobre o sentido do ser dos entes em geral e, portanto, essa tarefa possui um primado ontológico (também ôntico, como Heidegger mostra em seguida) sobre as ciências e suas ontologias regionais. Na medida em que qualquer fundamentação já precisa contar com um sentido de ser dado, "a questão sobre o ser visa às condições de possibilidade das próprias ontologias que antecedem e fundam as ciências ônticas" (HEIDEGGER, 2005, p.37). A filosofia, portanto, não pode de maneira alguma ser simplesmente reduzida ou comparada a uma ciência entre outras.

Contudo, não podemos desconsiderar o fato de no $\$ 7$ de Ser e tempo, por exemplo, a fenomenologia ser entendida como método para a realização da ontologia fundamental e ainda de que, a partir da discussão da etimologia da palavra "fenomenologia" e do conceito de "logos", Heidegger afirmar que a fenomenologia é a ciência dos fenômenos. A partir de uma longa argumentação que vincula fenômeno ao que aparece, isto é, à manifestação do ser dos entes, Heidegger pretende mostrar que a fenomenologia é ontologia na medida em que pergunta por essa aparição, por esse ser. Heidegger explica o que isso significa da seguinte forma: "Em seu conteúdo, a fenomenologia é a ciência do ser dos entes - é ontologia." (HEIDEGGER, 2005, p. 68, grifo nosso). A escolha dos termos ciência e método, em tal contexto histórico, não pode ser simplesmente enfraquecida ou desconsiderada. O mesmo acento pode ser igualmente observado no curso intitulado Os problemas básicos da fenomenologia, ministrado em 1927, mesmo ano de publicação de Ser e tempo. Aí Heidegger também usa termos e formulações que identificam a fenomenologia como "método da filosofia científica" (HEIDEGGER, 1982, p. 3). Heidegger afirma que, na Antiguidade, o termo filosofia significava o mesmo que ciência em geral. E que ainda que com o tempo as demais ciências tenham se autonomizado da filosofia, a filosofia permaneceria como essa ciência que engloba e abarca as demais ciências. Nesse sentido, filosofia é sempre ciência pura e simples e que o adjetivo 'científica' seria, de certa forma, um pleonasmo. Contudo, Heidegger defende que tal adjetivo deveria ser mantido para contraporse a outras concepções de filosofia contemporâneas que se compreenderiam, por exemplo, como visão de mundo. (HEIDEGGER, 1982, p. 3 e 4).

Nessa explicação fica claro que Heidegger pensa o termo ciência a partir de um resgate à noção de ciência antiga, que sem dúvida, nos textos de autores como Platão e Aristóteles, realmente se confundem e substituem indiferentemente pelo termo filosofia. A princípio, portanto, pareceria equivocado afirmar que o termo ciência surge na filosofia heideggeriana a partir de uma tensão com a noção de ciência moderna. Por outro lado, a necessidade de falar em "método" fenomenológico como um diferencial do "caráter científico" da filosofia que não é mera "visão de mundo" possui ressonâncias inegáveis com o problema do estatuto do conhecimento e a necessidade de afirmar seu caráter científico, que só vem à tona neste momento em que a filosofia já não encontra legitimidade em se compreender como metafísica clássica.

É necessário insistir na ressalva de que isso não pode ser reduzido a uma equivalência entre os termos ciência e filosofia (pensada como ontologia) no pensamento heideggeriano desenvolvido na década de 1920. Essa afirmação seria não apenas simplória, mas totalmente equivocada, pois como vimos, Heidegger mesmo faz, desde o início, uma distinção explícita e bastante forte entre esses conhecimentos, mostrando como a ontologia fundamental possui uma primazia ôntico-ontológica diante de qualquer outra ciência ôntica (DUARTE, 2004). O que tenho em vista com esses comentários é apenas apontar e problematizar uma patente preocupação heideggeriana nestes anos iniciais de assegurar o valor epistemológico de seus pensamentos filosóficos por meio da estratégia de adjetivá-los como científicos e pela aparição da palavra "método" em seus argumentos. Ou seja, ainda há aqui uma espécie de lastro do problema da legitimidade do pensamento filosófico na Modernidade que perpassa seus primeiros textos. 
Apenas em 1929/30 em Os conceitos fundamentais da Metafísica que Heidegger deixa de usar a noção de cientificidade para atribuir legitimidade ao conhecimento filosófico, diferenciando a filosofia da ciência, não apenas quanto seu objeto, mas completamente, isto é, em seu aspecto formal, suas diretrizes de legitimação e sua necessidade de auto-afirmação:

(...) se o que temos aqui [na filosofia] é um saltar questionável de uma opinião para outra em contraposição às verdades e aos progressos unissignificativos das ciências, aos seus assim chamados resultados assegurados?!? Aí está a fonte de todos os infortúnios. A filosofia, e a princípio mesmo como metafísica, ainda não atingiu a maturidade da ciência. Ela movimenta-se em um estágio que ficou para trás. O que ela vem tentando fazer desde Descartes, desde o começo da Modernidade, elevar-se ao patamar de uma ciência, da ciência absoluta, ainda não vingou. Desta maneira, precisamos empenhar todos os nossos esforços para que ela algum dia o consiga. (...)

Ou será que tudo o que diz respeito à filosofia enquanto ciência absoluta não passa de uma crença equivocada? Não apenas pelo fato de o singular ou de uma escola nunca alcançarem esta meta, mas porque, fundamentalmente falando, o próprio estabelecimento da meta é um equívoco e um desconhecimento da essência mais intrínseca da filosofia. Filosofia como ciência absoluta: um ideal elevado, inexcedível. Assim o parece. E, contudo, a própria avaliação da filosofia a partir da ideia de ciência talvez seja a forma mais funesta de degradação de sua essência mais intrínseca.

(...) Se olharmos tão-somente para o que nos precedeu até aqui, veremos que não apenas comparamos a filosofia com a ciência, como também quisemos determiná-la como ciência. (...) No entanto, a comparação da filosofia com a ciência é uma degradação injustificada de sua essência (HEIDEGGER, 2006, p. 2 e 3 ).

Nessa passagem e em toda a primeira parte do livro, o que parece estar em jogo é uma desvinculação completa da filosofia à ciência. Como Heidegger diz na passagem, o pretenso problema da "falta de cientificidade" da filosofia não é derivada do fato de ainda não termos encontrado bases firmes sobre as quais fundamentar a filosofia. O que falta não é continuar insistindo na busca por um método específico próprio da filosofia, mas, ao contrário, o reconhecimento de que comparar e, além disso, querer julgar a legitimidade da filosofia a partir da noção de produção de conhecimento assegurado pelo método das ciências naturais, que se alastra também pelas ciências humanas, é, em si mesmo, um equívoco completo. A partir daí Heidegger defende que a filosofia ainda não encontrou e nem encontrará um método adequado para assegurá-la como uma ciência rigorosa, absoluta ou primeira, porque o que está em jogo na filosofia não pode ser reduzido ao ideal de conhecimento moderno. E por mais que a crise da metafísica tenha instaurado a sugestão de que filosofia, ou bem, é história das diferentes "visões de mundo", ou precisa conquistar a cientificidade de seu conhecimento, ambas as concepções passam ao largo do desafio de se pensar a filosofia para além dos parâmetros estritamente modernos de conhecimento e, nesse sentido, para o autor, perdem a própria essência da filosofia. A razão do equívoco sobre a essência da filosofia consiste no seguinte: na medida em que a filosofia se propõe questionar radicalmente o ser dos entes, quando aprisionada a uma instauração do sentido do ser dos entes específica, tal como se consolida na modernidade, essa tarefa não pode ser realizada plenamente. Quer dizer, no momento em que a filosofia retira sua consistência do paradigma da ciência, ela já está circunscrita a uma ontologia específica (para usar os termos de Ser e tempo) e assim não pode desempenhar sua tarefa de levar a cabo uma ontologia fundamental. Se a filosofia estiver submissa a uma compreensão de conhecimento assegurado pelo método, ela perde a possibilidade de questionar o horizonte de sentido que compreende conhecimento como certeza e determina as diretrizes da produção científica. Por isso, Heidegger pode concluir: "Por fim, a interpretação da filosofia como proclamação de uma visão de mundo encerra o mesmo engodo que a sua caracterização como ciência. Filosofia (metafísica): nem ciência, nem proclamação de uma visão de mundo" (HEIDEGGER, 2006, p. 3). Essa última formulação marca, portanto, uma ruptura importante com formulações anteriores que qualificavam a fenomenologia como filosofia científica e permite um resgate da legitimidade da metafísica. 
Mas, como vimos, isso só ocorre a partir dos textos da década de 1930, ou seja, praticamente cem anos depois da morte de Hegel e do momento de consolidação das ciências na Alemanha.

Aqui não nos interessa, contudo, acompanhar em detalhes as transformações no pensamento heideggeriano, senão, evidenciar como a primeira fase de seu pensamento ainda é marcada por essa característica que perpassa grande parte dos autores alemães deste momento, a saber, a busca pela cientificidade da filosofia. Isso traz à tona a maneira como, na Alemanha, a partir da década de 1830, o abandono da tarefa metafísica pela busca da verdade é substituído, em um primeiro momento, pela necessidade de elaboração do método assegurador dos resultados. Como vimos, a preocupação com o método se concretiza de maneira paradigmática em sua conjugação com o modelo positivista de ciências naturais (que, como acabamos de comentar, também se transformou no paradigma das ciências humanas e, em certo sentido, da própria filosofia), mas não se resume a ele, pois mesmos autores claramente anti-positivistas como Dilthey, Husserl e Heidegger, de uma maneira ou de outra, ainda pensarão a legitimidade do conhecimento atrelado ao método.

Por outro lado, Nietzsche vê na recusa por princípios metafísicos conjugada com a busca por certeza, presente, sobretudo, no ideal moderno positivista das ciências naturais, ainda um resquício de crença metafísica:

\begin{abstract}
Alguns ainda precisam da metafísica; mas também a impetuosa exigência de certeza que hoje se espalha de modo científico-positivista por grande número de pessoas, a exigência de querer ter algo firme (enquanto, no calor desta exigência, a fundamentação da certeza é tratada com maior ligeireza e descuido): também isso é ainda exigência de apoio, de suporte, em suma, o instinto de fraqueza que, é verdade, não cria religiões, metafísicas, conviç̧ões de todo tipo - mas as conserva. (NIETZSCHE, 2001, \$347, p. 240).
\end{abstract}

Para ele, essa necessidade de segurança pretensamente alcançada através do método ainda é um sintoma da devoção ao que ele denomina vontade de verdade a todo custo. É por isso que no aforismo 343 de A Gaia Ciência e nos parágrafos 24 e 27 da segunda dissertação de Genealogia da Moral, Nietzsche afirma que, de certa forma, a ciência ainda é devota ou segue o ideal ascético. E isso porque ela teria herdado da moralidade cristã a crença no valor supremo da verdade a todo custo, sacrificando todas as demais convicções a esta última convicção suprema: "Porque o ideal ascético foi até agora senhor de toda filosofia, porque a verdade foi entronizada como Ser, como Deus, como instância suprema, porque a verdade não podia em absoluto ser um problema" (NIETZSCHE, 1998, \$24, p. 140). Em nome da verdade, que foi entronada como valor supremo pela metafísica ao identificá-la inicialmente com o ser e com Deus, o ateísmo (representando, de forma geral, o movimento de secularização da ciência e do conhecimento na modernidade) recusa a existência de Deus como uma mentira (NIETZSCHE, 1998, \$27, p. 147). A partir dessa recusa, a ciência persegue um conhecimento que abandone qualquer convicção prévia (NIETZSCHE, 2001, \$ 357, p. 255 e 256). Mas, esse abandono é ainda fruto da crença no valor irrestrito da verdade. Isto é, a recusa da ciência por crenças ou filosofias metafísicas e sua busca pelo método, pela evidência, pelo empírico ou pelo matematicamente controlável consistiria, mais uma vez, pela mesma busca pela verdade a todo preço, realizada pela metafísica. Justamente por isso, para Nietzsche surge a tarefa, pela primeira vez na história do ocidente, de questionar o próprio valor da verdade. Para o autor, essa é a maneira como a própria vontade de verdade enquanto moral cristã vai se auto-superar, suprimindo definitivamente seu pressuposto inquestionável.

Esse movimento de questionar o valor da verdade se for pensado juntamente com a crise da mecânica clássica, que leva a um desmoronamento do ideal positivista de ciência e que será discutido na segunda parte deste trabalho, parece consumar, de certa forma, o abandono pela busca pela verdade em um sentido forte. Cada vez mais, mesmo a crença no método vai se mostrando insuficiente para garantir a legitimidade epistemológica da produção de conhecimento e paulatinamente a filosofia e a ciência vão abrindo mão de tentar fundamentar absolutamente seu conhecimento, seja em termos realistas ou idealistas. Essa dificuldade vai se revelando não um fruto contingente decorrente de uma má escolha do modelo ou paradigma de conhecimento adotado (isto é, religioso, metafísico ou científico), mas muito mais uma impossibilidade derivada da própria finitude e limites inerentes ao ser humano e suas capacidades cognitivas. É sobre essa maneira de 
entender a tarefa do pensamento, como a pergunta sobre os limites e condicionamento do ser humano que vamos nos debruçar na segunda parte desse trabalho, a partir do retorno à filosofia de Kant.

\section{A Crise da física na passagem do séc. KIK para o KK e o retorno à filosofia de kant}

Já a partir da década de 1850, o cenário das ciências naturais em toda a Europa se complexifica de tal maneira que o ideal positivista da pura observação e descrição dos fenômenos da natureza não pode mais ser sustentado. Sendo a física neste momento considerada o modelo de ciência moderna (VIDEIRA, 2011, p.191), tal crise foi trazida à tona justamente por debates centrados no questionamento dos fundamentos básicos da física de então. Fatores muitas vezes internos a discussões da mecânica clássica (comuns no final do séc. XIX) ${ }^{9}$, levaram os cientistas a se questionarem sobre a própria natureza e objetivos do conhecimento científico e, neste sentido, das possibilidades do conhecimento, suas metodologias e preceitos básicos. Como dissemos, na medida em que a mecânica clássica sustentava a própria concepção de ciência natural, tal como entendida até então, o questionamento de suas bases não significou simplesmente a reestruturação ou ruptura de teses mecanicistas, mas também a crise do próprio modelo consolidado pela mecânica, que serviu de exemplo e modelo para a construção do ideal moderno de ciência (MOREIRA, 1995, p. 33).

Poderíamos considerar que o problema central, responsável por grande parte dos questionamentos, estava ligado à concepção de que a tarefa da ciência era apenas descrever os fenômenos naturais. Tal concepção incluía a pretensão, discutida anteriormente, de que conhecimento científico estava disponível na própria natureza, bastando ao cientista formulá-lo em leis, a partir da observação criteriosa e do uso da linguagem adequada. Com o desenvolvimento da mecânica, porém, essa concepção foi sendo colocada em xeque, uma vez que alguns fundamentos e conceitos se tornavam cada vez mais problemáticos e difíceis de se sustentar frente às novas observações e formulações. Com o avanço de técnicas para experimentações empíricas e o desenvolvimento das formulações teóricas e, portanto, complexificação da semântica e ampliação das possibilidades de abstrações matemáticas, cada vez mais abrangentes, começaram a surgir divergências quanto a conceitos e enunciados mais adequados para descrição e explicações de determinados fenômenos ${ }^{10}$.

Isso significa que os cientistas passaram a se confrontar com formulações distintas para as mesmas teorias, que igualmente "funcionavam", isso é, davam conta do fenômeno em questão (COELHO, 2012, p.21). Contudo, na medida em que a pretensão científica positivista era a de descrever os fenômenos por meio da formulação de leis baseadas apenas na objetividade da natureza que garantiam sua universalidade, como entender a possibilidade de pluralidade de enunciados distintos sobre um mesmo fenômeno? E, de maneira ainda mais radical, se tais enunciados possuem a mesma capacidade de previsão de fenômenos, como valorá-los, como escolher um em detrimento do outro?

O surgimento de várias e diferentes tentativas de solução para os impasses emergentes do desenvolvimento da física mecânica clássica trouxe à tona, portanto, a pluralidade das possibilidades de representação dos fenômenos. Tal pluralismo, por sua vez, questionava diretamente a noção de que as leis da natureza são formuladas com base apenas nos dados sensíveis, empiricamente observáveis, na medida em que podemos utilizar distintas opções de enunciados, igualmente legitimáveis empiricamente. A partir disso tornou-se necessário determinar o papel da idealização do fenômeno para a formulação das leis e teorias (CASSIRER, 1953, p. 170). Isto é, passou a ser necessário discutir qual é o papel do sujeito na formulação das leis e teorias científicas. Em outras palavras, isso significa dizer que se instaurou um retorno à problemática kantiana.

\footnotetext{
"Vários fatores influenciaram as tentativas de revisão da mecânica clássica do século XIX. Entre eles podem ser citados: a introdução do conceito de energia; a busca de uma descrição mecânica para os fenômenos eletromagnéticos; a procura de uma conciliação da termodinâmica com a mecânica, onde a explicação da segunda lei em termos mecânicos era um obstáculo significativo; a construção de uma estrutura teórica para a mecânica que fosse logicamente mais perfeita e livre de alguns problemas já identificados por Kirchhoff e Mach e, finalmente, a tentativa de compatibilizar a visão mecanicista com o desenvolvimento dos estudos sobre os seres vivos. Diante desse quadro, os mecanicistas mais destacados são forçados a rever e a refinar suas posições" (MOREIRA, 1995, p. 33).

10 Temos em vista aqui, sobretudo, a discussão ao redor dos conceitos de força e energia, que resultou em soluções consideravelmente diversas para as mesmas questões.
} 
Com a crise no ideal positivista de pura descrição objetiva dos fenômenos, a ideia de que teorias científicas são representações do sujeito retoma espaço e precisa ser devidamente fundamentada a fim de garantir a legitimidade do conhecimento científico. Se o papel do sujeito na produção de conhecimento não é meramente passivo, mas também ativo, é necessário voltarmos aos problemas sobre o estatuto da representação dos fenômenos. Precisamos questionar nosso "aparato representativo", a fim de tentar fundamentar o conhecimento científico por meio da delimitação de sua participação na produção do conhecimento científico. A relação com a filosofia kantiana, portanto, se torna evidente e novamente se pergunta pelos limites do conhecimento humano a partir do sujeito e não simplesmente do objeto. Perguntas sobre qual é o papel do sujeito na produção de teorias científicas, qual é o estatuto da representação, se existe alguma estrutura $a$ priori da razão humana e como ela se relaciona com a sensibilidade passam a ser perguntas da ordem do dia.

O pluralismo teórico levanta não apenas tal impasse sobre o papel da subjetividade nas teorias científicas, mas também o problema da validade das teorias. Como diferenciar e eleger uma formulação em detrimento de outra? Quais critérios devem ser levados em consideração já que o ideal de pura observação não é suficiente? No interior de tais questionamentos, grande parte dos principais cientistas da época demonstrou a necessidade de restabelecer os laços entre a especulação filosófica e a ciência. Importantes nomes desse período como Helmholtz, Boltzmann, Poincaré, Duhem, Hertz, entre outros, por mais que apresentassem divergências em suas ponderações, se dedicaram a repensar os objetivos e fundamentos da ciência (VIDEIRA, 2013). Esse retorno à filosofia foi, desta maneira, fortemente marcado pela concepção de filosofia como epistemologia e mesmo o evidente retorno à filosofia de Kant, que ocorreu especialmente na Alemanha, foi determinado pela noção de que a filosofia deveria ocupar o papel de fundamentação das ciências.

Os filósofos neokantianos, tal como foram chamados, encontraram nessa relação entre ciência e filosofia uma tarefa para a filosofia, que parecia ter perdido seu espaço específico com a morte dos sistemas metafísicos. Isto é, entre boa parte do movimento denominado neokantismo na Alemanha, o que estava em jogo, em um primeiro momento, era transformar a filosofia em teoria do conhecimento. A filosofia deveria se limitar a discutir os problemas epistemológicos que surgissem no interior da prática científica, abrindo mão, o máximo possível, de posições metafísicas mais fortes (LOPES, 2008, p. 43).

O que foi denominado neokantismo foi intimamente associado à escola de Marburg, liderada principalmente pelos trabalhos de Hermann Cohen (1848-1918) e Paul Natorp (1854-1924). A obra de juventude de Cohen intitulada A teoria da experiência de Kant (1871), que assumiu uma posição fortemente antimetafísica e defendeu uma filosofia cientificamente orientada, foi de grande influência na Alemanha até os anos de 1920 (GORDON, 2012, p. 52 e 53). Além de Marburg, havia ainda na Alemanha a escola de Baden (também conhecida como a escola do sul ou sudoeste), lideradas por Wilhelm Windelband (1848-1915) e, após a sua morte em 1915, por Heinrich Rickert (1863-1936) e Emil Lask (1875-1915). A escola de Baden, em oposição à escola de Marburg, defendia que o que deveria ser retomado da filosofia kantiana era a "primazia da razão prática", a fim de fundamentar uma filosofia dos valores e da cultura. Ambas as escolas concordavam em relação ao aspecto transcendental que toda fundamentação filosófica deveria possuir. A noção de transcendental, nestas duas escolas, estava restrita ao puramente epistemológico, em oposição ao metafísico, ao relativismo histórico ou psicologismo, que a escola de Baden queria combater com sua fundamentação dos valores universais.

Contudo, o "retorno a Kant" não pode ser reduzido a estes dois movimentos. Antes do seu surgimento, já em 1855, em uma conferência em Köningsberg, Hermann von Helmholtz (1821-1894) havia colocado Kant no centro do debate, não apenas filosófico, mas também científico, ao associar algumas das descobertas da fisiologia dos órgãos sensoriais da época às teses kantianas. Essa associação, que teve ampla repercussão nas discussões epistemológicas, inaugurou uma via idealista de crítica ao positivismo materialista que era demasiado estreita e insuficiente para a pluralidade dos resultados das ciências que não se encaixavam na mecânica clássica. Sua grande inovação consistia no fato de ele propor uma defesa do idealismo baseado em resultados das próprias ciências, isto é, Helmholtz propôs interpretarmos a estrutura transcendental da razão humana a partir de resultados empíricos sobre os órgãos sensoriais. Apesar da evidente contradição com o 
projeto kantiano de uma filosofia a priori que não dependesse da experiência para ser demonstrada (uma vez que era sua própria condição de possibilidade), a conferência foi responsável por iniciar um grande debate de questões kantianas na Alemanha no meio científico (LOPES, 2008, p. 44).

Temos por um lado, portanto, as ciências naturais voltando à filosofia de Kant para re-fundamentar sua legitimidade, posta em questão pela crise do modelo positivista e da mecânica clássica. Esse retorno é marcado, sobretudo, por uma apropriação específica da filosofia kantiana, que podemos denominar o projeto de naturalização do transcendental. Tal empreitada pretendia descrever as condições de possibilidade físicas e fisiológicas de nossa experiência, discutindo, a partir deste viés, a relação do sujeito na construção do conhecimento científico.

Por outro lado, temos a filosofia tentando discutir e encontrar que tarefa lhe restou frente à hegemonia das ciências naturais. Em grande medida, ou pelo menos inicialmente, houve uma forte tendência de limitar a tarefa da filosofia à de teoria do conhecimento, afirmado assim, uma espécie de relação inevitável com as ciências, que assumiriam o papel de produção de conhecimento sobre o mundo, enquanto a filosofia deveria se limitar a discutir os limites, impasses, consequências, estatutos etc. deste conhecimento. No meio destas duas apropriações da filosofia kantiana, se encontram ainda as ciências humanas, que precisam encontrar fundamentos para se legitimar enquanto conhecimento científico a partir de sua especificidade.

Poderíamos citar, a título de ilustração, a obra de Dilthey, que propôs uma crítica da razão histórica, em clara referência a Kant, como exemplo deste tipo de apropriação da filosofia kantiana. Para a hermenêutica de Dilthey não é somente a compreensão do discurso do outro que está em jogo, mas, ao contrário, a tentativa de determinar a metodologia específica e apropriada às ciências humanas. Em uma relação direta com o projeto kantiano da Crítica da Razão Pura enquanto fundamentação do conhecimento humano no âmbito da matemática e das ciências naturais, Dilthey define o objetivo da hermenêutica como uma crítica da razão histórica. Esse título alude ao fato de que, devido ao caráter histórico dos fenômenos estudados pelas ciências humanas, as categorias envolvidas nesse tipo de conhecimento são diversas das descritas por Kant. O principal problema da crítica kantiana, para Dilthey, é que ela tomou a lógica formal e a matemática como o modelo para pensar os limites do conhecimento humano e, a partir desses limites, fundamentar as proposições científicas. Contudo, tal procedimento parte de uma abstração e recorte dos fenômenos que é incompatível com a natureza dos fenômenos da vida e da história em geral, e, portanto, inadequado para as ciências humanas. Os fenômenos das ciências humanas são dados a partir de vivências e, por isso, não são objetos que possam ser posicionados e abstraídos do fluxo da própria vida. Para Dilthey, a tarefa que precisa ser levada a cabo consiste em uma espécie de complementação da crítica kantiana. É necessária agora uma crítica que procure determinar as categorias adequadas aos fenômenos históricos e, destarte, sejam capazes de fundamentar as ciências humanas a partir de sua especificidade.

É interessante reparar, contudo, a importância que esse retorno a Kant representou para o pensamento alemão deste período, na medida em que tanto a tarefa da filosofia, como as ciências humanas, e a das ciências naturais, viram em Kant uma fonte ou um ponto de partida para superar seus desafios e buscar fundamentações para a legitimidade de seu conhecimento. É claro que a maneira de interpretar a filosofia kantiana ou mesmo de se apropriar da maneira como sua empreitada deveria ser levada a diante, diferem muito não apenas em cada um desses setores: filosofia, ciências humanas e ciências naturais, mas ainda, em cada autor que se dedicou a realizar tal retorno. Como vimos, esse retorno a Kant ocorre também logo após a decadência do pensamento hegeliano e de sua herança imediata na Alemanha.

\section{A influência de Kant para a filosofia de Nietzsche: um debate sobre Lange e a naturalização do transcendental}

Nas últimas décadas tanto no Brasil, quanto no cenário internacional, tem se multiplicado o número de trabalhos dedicados a reconstruir as influências de determinados autores, que poderíamos chamar de maneira genérica de neokantianos ou proto-neokantianos, como Friedrich Albert Lange (1828-1875), 
Hermann von Helmholtz (1821-1894) e a Afrikan Spir (1837-1890) sobre o pensamento de Nietzsche. O que geralmente se defende é que a vinculação de Nietzsche à tradição transcendental não apenas é mediada por esses autores, mas que Nietzsche se filiaria às transformações no projeto kantiano que tais autores propõem. $\mathrm{Na}$ maioria das vezes, o autor que ocupa o centro das discussões é Lange e seu projeto de naturalização do transcendental, debitário dos resultados empíricos das pesquisas de Helmholtz. Por outro lado, também podemos encontrar trabalhos sobre outras influências sobre Nietzsche, como a de Spir, que seriam evidências do contrário (GREEN, 2002). Meu objetivo aqui é reconstruir, em linhas gerais, como essa relação tem sido tratada e, em seguida, sugerir que tal modo de pensar a vinculação de Nietzsche à filosofia transcendental em termos de influências de autores (proto) neokantianos podem perder de vista o mais importante desta vinculação: exatamente o acento incansável da filosofia nietzschiana na finitude do ser humano. No intuito de reconstruir de maneira mais clara o que se defende, aqui não será realizada uma crítica incessante às teses. A reconstrução dos argumentos, contudo, não deve ser confundida com adesão aos mesmos. Com o avançar da argumentação, espera-se que os pontos de discordância se tornem claros.

\subsection{As influências da filosofia transcendental no pensamento nietzschiano}

Desde a monografia de George J. Stack ${ }^{11}$ (1983), exclusivamente dedicada a mostrar a influência inegável (e até mesmo devastadora, segundo a proposta do autor) da obra de Lange na filosofia de Nietzsche, a questão sobre $o$ aspecto transcendental na filosofia nietzschiana tem ganhado muitos adeptos e espaço para discussão no cenário acadêmico. Boa parte dessa discussão gira em torno da naturalização do transcendental que havia sido defendida por Lange, que muitos identificam em Nietzsche, em afirmações recorrentes em sua obra sobre condições de possibilidade de vida. O que está em jogo nessa frase é uma recolocação do problema kantiano sobre as condições de possibilidade do entendimento (tarefa da filosofia transcendental da subjetividade) em termos, sobretudo, biológicos e empíricos em geral. Quer dizer, a estrutura transcendental em jogo seria transportada da noção de subjetividade para a noção de vida, a fim de descrever as condições fisiológicas e históricas que permitiram determinados tipos de vida se estabelecerem. Para entender o que está em jogo nesse debate, precisamos rapidamente reconstruir alguns pontos principais da filosofia de Lange.

Friedrich Albert Lange foi professor em Zürich e Maburg e sua principal obra, intitulada História do materialismo [Geschichte des Materialismus], foi publicada em 1866. Esta obra consiste em uma história do materialismo desde a Grécia antiga até a sua época, na qual havia um importante debate sobre os limites e alcance do materialismo, entendido como uma posição positivista materialista. Como Lopes resume de maneira lapidar, podemos apresentar:

(...) a tese central de Lange nos seguintes termos: enquanto método ou estratégia cognitiva o materialismo deve ser cultivado, enquanto posição epistemológica ele está refutado, enquanto tese ontológica é indemonstrável e enquanto visão de mundo ele deve ser moderadamente combatido (LOPES, 2008, p. 48).

Essas diferenciações que Lange propõe entre método, posição epistemológica, tese ontológica e visão de mundo são fundamentais para entender a sofisticada argumentação "contra" e "a favor" do materialismo presente em sua obra. Tal argumentação possui desdobramentos importantes no pensamento de Nietzsche. Para Lange, o materialismo consiste na postura epistemológica mais virtuosa ao limitar e orientar seu escopo aos objetos naturais, visando à simplicidade e à sobriedade e evitando, assim, grandes especulações metafísicas "fantasiosas". Nesse sentido, o materialismo estimula e é compatível com a economia metodológica adequada ao pensamento científico moderno. Por outro lado, enquanto posição epistemológica ele está refutado uma vez que a própria ciência mostrou que não possuímos um acesso direto aos objetos

11 Stack não foi o primeiro a defender a influência de Lange para a filosofia nietzschiana. Já em 1908, Raoul Richter havia contestado a supremacia absoluta da influência de Schopenhauer, ao considerar a importância da obra História do Materialismo de Lange para o jovem Nietzsche. Jörg Salaquarda retoma o tema em dois artigos em 1978 e 1979 (LOPES, 2008, pp. 35 -40). 
naturais. Aqui, Lange apresenta uma interessante estratégia argumentativa na medida em que ele tomará o idealismo e o materialismo como posições que devem se criticar e corrigir mutuamente, possibilitando uma superação crítica do materialismo dogmático. O que Lange faz, em linhas gerais, é se apropriar da posição de Helmholtz, que defendeu que os resultados de pesquisas empíricas sobre os órgãos fisiológicos comprovariam a existência de uma estrutura $a$ priori de intelecção humana dos fenômenos (LANGE, 1903, tomo II, p. 27 e 28 ).

Desta maneira, Lange defende que os resultados alcançados por meio das ciências naturais, fortemente determinadas por princípios materialistas, refutariam a concepção positivista materialista de acesso direto aos fenômenos, ao demonstrar como as nossas percepções fenomênicas dependem de estruturas prévias determinadas pela organização de nossos órgãos sensoriais. Isto quer dizer que a pesquisa empírica sobre nossa fisiologia refutaria o materialismo enquanto posição epistemológica ao confirmar a existência de certa estrutura transcendental e, portanto, "provar empiricamente" uma espécie de idealismo, que restringe nossa experiência aos fenômenos, dada a constituição dos órgãos sensoriais. Pela mesma razão, enquanto tese ontológica, o materialismo seria completamente indemonstrável, por não existir uma maneira de provar a natureza dos objetos empíricos para além de sua configuração fenomênica, nem tampouco afirmar qualquer tipo de adequação. E isso porque todo acesso aos fenômenos já sempre seria mediado pelos órgãos sensoriais e por suas estruturas específicas de conformação dos fenômenos.

Para Lange, a especulação filosófica própria à crítica kantiana já havia sido capaz de mostrar o equívoco em que se baseia o materialismo dogmático. Por outro lado, o resultado das investigações no campo da fisiologia, ao mesmo tempo em que prova cientificamente a existência de uma certa estrutura prévia que determina nossa sensibilidade, corrige a especulação puramente transcendental, na medida em que confirma a tese de que haja uma estrutura a priori, mas refuta a pretensão de que essa estrutura possa ser descrita igualmente a priori (LANGE, 1903, II, p. 39).

Uma formulação lapidar nos mostra claramente o que está em jogo para ele:

A ponta afiada da foice que corta pela raiz tanto o materialismo quanto o idealismo repousa sempre na crítica, ou seja, no ceticismo que se tornou disciplinado e metódico. Este nos ensina que nosso inteiro conhecimento, fundado nos sentidos e no entendimento, nos mostra apenas um lado da verdade. O outro lado nós não podemos conhecer nem através da ciência, nem da fé, nem da metafísica nem de qualquer outro meio (LANGE, 1866, p.276 apud LOPES 2008, p. 74).

Para Lange, através da crítica idealista ao materialismo dogmático o que se alcança não é um idealismo puro ou metafísico, mas, ao contrário, é um ceticismo "metódico e disciplinado", no qual se nega qualquer posição ontológica materialista ou idealista, se aceita um idealismo epistemológico moderado e se abraça um materialismo como princípio orientador do método para as ciências naturais. A consequência imediata destas posições é um enfraquecimento no estatuto epistemológico da verdade objetiva produzida pelas ciências naturais, mas, sobretudo, do próprio estatuto do conhecimento a priori das condições de possibilidade de todo conhecimento humano. Uma vez que a descrição dos princípios a priori não pode ser feita de maneira igualmente a priori como pretendia Kant, mas apenas por meio de observações empíricas, não podemos nos assegurar de sua validade universal e atemporal. Quer dizer, não possuímos meios de garantir que eles sejam "fundamentais a todo conhecimento humano" ao invés de meros "erros a priori”: princípios passageiros derivados apenas de um "certo grau de desenvolvimento" do ser humano. Isto é, podemos afirmar com segurança que existem princípios a priori, mas não podemos determiná-los de maneira a priori, pois não possuímos uma maneira de diferenciar os verdadeiros princípios a priori dos erros a priori. Para tais determinações, podemos contar apenas com o mesmo procedimento das ciências naturais que é, invariavelmente, indeterminado e baseado em aproximações e teses prováveis e nunca alcança um conhecimento apodítico. Nas palavras de Lange: 
O que ocorre com o falso conhecimento a priori não é em nada distinto do que acontece com o conhecimento a priori em geral. Na maioria das vezes não se trata de uma proposição empírica adquirida de forma inconsciente, mas de uma proposição cuja necessidade está dada anteriormente a toda experiência particular através da organização psicofísica do homem, e que por essa razão surge juntamente com a primeira experiência sem o intermédio da indução. Esta proposição é, contudo, aniquilada com a mesma necessidade, graças a conceitos a priori mais profundamente arraigados, tão logo uma série de experiências tenha conferido preponderância a estes últimos. Embora ambas as classes de conhecimento a priori estejam igualmente ligadas à consciência da necessidade, seria preciso que o metafísico pudesse diferenciar dentre os conceitos a priori aqueles que são permanentes, que pertencem essencialmente à natureza humana, e aqueles que são passageiros, que correspondem apenas a um grau determinado de seu desenvolvimento. Para tanto ele não pode se servir de novo de uma proposição a priori e nem tampouco do chamado pensamento puro, pois está em questão justamente se os princípios deste têm um valor permanente ou não. Estamos, portanto, completamente reduzidos, na investigação e exame das proposições gerais que não provêm da experiência, aos procedimentos ordinários da ciência; não podemos propor mais que teses prováveis sobre a questão de saber se as ideias e as formas de pensamento que nos vemos obrigados a admitir como verdadeiras, sem nenhuma prova, se derivam ou não da natureza permanente do homem. Em outras palavras, se são verdadeiras ideias fundamentais de todo conhecimento humano ou se acabarão sendo descartadas como “erros a priori" (LANGE, 1903, p. 40 e $41^{12}$ ).

Contudo, se não podemos nos assegurar nem mesmo do caráter a priori dos princípios que se mostram como a priori em nossa estrutura de acesso ao fenômeno, tampouco podemos nos assegurar da verdade objetiva sobre esses fenômenos. As ciências, desta maneira, precisam assumir seu caráter ficcional de sistematização de fenômenos tais como eles aparecem para nossos aparelhos sensoriais e cognitivos, que contam com uma organização específica, marcando a finitude do ser humano e os limites de seu conhecimento. Essas sistematizações, no entanto, são falseáveis e ampliadas conforme o desenvolvimento tanto de nossa sistematização, quanto de nossos próprios aparelhos cognitivos ou nosso conhecimento sobre eles. Se por um lado há uma contraposição entre princípios comuns a todos os homens, que, portanto, ainda seriam "verdadeiros", e os meramente provisórios, que seriam "erros", por outro, não possuímos nenhum tipo de acesso privilegiado, como pretendia Kant, a tais princípios, de forma que pudéssemos nos assegurar desta distinção. A única via que temos para conhecê-los é a científica, marcada por seu caráter provisório e probabilista em contraposição ao conhecimento a priori universal e imutável da filosofia transcendental estrita.

Como os princípios a priori podem se mostrar como erros a priori por não passarem de estágios específicos de desenvolvimento de nosso organismo ou mesmo de nossa sistematização destes princípios, o conhecimento da ciência assume um caráter falibilista que opera por falsificação constante de seus enunciados, que sempre tendem a incluir um conjunto maior de enunciados e convicções de base (LOPES, 2008, p. 73). Esta posição ao mesmo tempo em que generaliza o caráter ficcional de todo conhecimento, defende a necessidade normativa destas sistematizações cognitivas e epistemológicas. Para Lange, não temos outra (ou melhor) saída que assumir o materialismo como estratégia cognitiva, uma vez que não possuímos mais do que o acesso aos fenômenos naturais para forjar nosso conhecimento. Caberia desta maneira à filosofia tal papel crítico constante, de apontar continuamente o caráter ficcional de todo conhecimento científico, combatendo, assim, um materialismo dogmático, ao mesmo tempo em que deve recusar qualquer formulação idealista metafísica sobre a possibilidade de descrever e determinar a priori essa estrutura transcendental a partir da qual já sempre partimos, evitando a absolutização da posição idealista.

12 Na primeira parte da citação utilizei a tradução de Rogério Lopes disponibilizada em sua tese como uma citação nas páginas 63 e 64 . O final da citação (a partir da parte "Estamos, portanto, completamente reduzidos..." em diante) foi traduzido por mim da versão em espanhol anteriormente citada. 
É, de fato, interessante destacar o uso de expressões como "erros a priori" ou "ficções", na medida em que elas parecem perpassar toda a obra nietzschiana. Por mais que existam evidências de que o contato de Nietzsche com a História do materialismo de Lange tenha sido por volta de 1866 e seu impacto sentido mais fortemente em sua obra de juventude, essa influência parece ter marcado a obra nietzschiana até o final. Se analisarmos alguns aforismos de Além do Bem e do $\mathrm{Mal}^{13}$, por exemplo, fica claro como essas expressões seguem vigentes e como aparecem articuladas a um contexto de crítica à filosofia kantiana. Rogério Lopes realiza um estudo muito detalhado sobre essa influência, com citação de cartas e textos, assim como documentações biográficas e bibliográficas da impressão que os escritos de Lange exerceram sobre Nietzsche e de seu desdobramento no decorrer de sua filosofia (LOPES, 2008, p. 27-185). Esse autor analisa detalhadamente cartas e póstumos deste período que mostram não apenas o grande entusiasmo de Nietzsche com Lange, mas também como as considerações de Lange sobre os limites cognitivos e perceptivos humano teriam ajudado Nietzsche a chegar à conclusão sobre aporias filosóficas clássicas entre realismo e idealismo e sobre o papel normativo que a filosofia deveria desempenhar, ainda que não possa se fundamentar plenamente (apesar dos intuitos e esforços da tradição neste âmbito).

Além disso, dada essa impossibilidade de fundamentação última, Lange defendeu que a filosofia precisava assumir o papel de elaborar sistemas que pudessem fornecer um sentido ao todo, reconhecendo seu papel edificante e idealizante por meio das ficções conceituais que a especulação gera. Nesse sentido, por mais que não haja qualquer possibilidade de reivindicar uma verdade objetiva para os sistemas filosóficos uma vez que não possuímos qualquer acesso ou possibilidade de transpor nossos limites cognitivos, eles têm sua legitimidade e justificação resguardadas na medida em que fornecem um ideal para guiar a cultura e os comportamentos humanos.

Em linhas gerais, essas posições marcaram profundamente a reflexão nietzschiana por toda a sua obra. A preocupação em como justificar a filosofia, ou mais ainda, o questionamento sobre sua capacidade de atuar e transformar a cultura, mesmo abrindo mão da ilusão dogmática de uma fundamentação efetiva dos princípios filosóficos, parece ter motivado sempre o esforço nietzschiano de pensamento. Essa preocupação seria capaz de explicar algumas posições que por vezes parecem contraditórias, ou no mínimo, difíceis de serem conciliadas com a teoria do erro ou o ficcionalismo nietzschiano, a vontade de poder e o perspectivismo.

Alguns comentadores atuais ${ }^{14}$ têm se esforçado para mostrar que a influência de Lange em Nietzsche se traduziria em um compromisso irrestrito de naturalização do transcendental, não apenas em um sentido biológico, mas também histórico-social. Tal compromisso levaria Nietzsche a assumir um certo naturalismo, que poderíamos chamar de uma espécie de empirismo pós-positivista ou uma posição cientificista de legitimação dos resultados da ciência, mesmo com sua restrição fenomênica e ficcional, por ser o único tipo de conhecimento humano possível. A ideia principal de tal posição seria que a investigação sobre os limites ou as condições de possibilidade do conhecimento humano só poderia ser levada a cabo por pesquisas empíricas. Em outras palavras, que as próprias ciências deveriam ser o caminho para realizar a crítica sobre nossos limites cognitivos, o que tornaria não apenas supérflua, mas ainda ilegítima a especulação transcendental no campo estritamente filosófico.

De fato, em alguns aforismos, Nietzsche defende de maneira bastante enfática que nossas "condições transcendentais" seriam fruto de processos contingentes. Beatrice Han-Pile afirma que tal "gênese empírica" seria uma forte evidência de elementos naturalistas na filosofia nietzschiana. Ela diz que em Nietzsche: "Os elementos 'transcendentais' da percepção possuem uma gênese empírica: eles têm sua condição de possibilidade causais no surgimento de novas práticas (tais como a vida social) e sua necessidade é apenas relativa a essas práticas (HAN-PILE, 2011, p. 192). Por esta razão, tal autora considera que a posição de Nietzsche consiste em assumir um "transcendental deflacionário" e isso porque por um lado, Nietzsche assumiria précondições não empíricas para a percepção humana, isto é, a existência de uma estrutura prévia e anterior

13 Ver aforismos 4, 11, 25, entre outros.

14 Especialmente Maudemarie Clark and Brian Leiter, mas também, em certa medida, o próprio Stack e John Richardson, entre outros. 
que determina como algo pode ser experimentado. Mas, por outro lado, essa estrutura mesma dependeria de circunstâncias empíricas específicas e por isso, se essas circunstâncias se alterarem, tal estrutura perderia seu poder normativo. Como vimos, nesta posição encontramos uma ressonância direta da posição de Lange em sua diferenciação entre princípios efetivamente a priori e erros a priori, para a qual, apesar de estes últimos desempenharem o papel de condição de possibilidade, são apenas o resultado de um estágio específico de desenvolvimento do ser humano, que pode ser alterado tão logo essas circunstâncias mudem. Isso, contudo, claramente nega a pretensão kantiana de universalidade na descrição transcendental da razão humana. Como Han-Pile argumenta, tais restrições transcendentais apenas podem ser consideradas a priori a partir de uma "perspectiva sincrônica" (HAN-PILE, 2011, p. 193). Isto é, elas são a priori na medida em que condicionam e possibilitam a experiência, mas são a posteriori uma vez que são derivadas de práticas ou situações específicas. Sua validade, portanto, não pode ser fundamentada em uma base "puramente racional", mas, ao contrário, dependem das práticas que lhes deram origem. Obviamente, desta maneira se nega a possibilidade de defender uma validade universal dessas condições e se restringe a ideia de objetividade a situações determinadas por condicionantes particulares.

John Richardson, a partir de uma abordagem mais pró-naturalista, defende algo similar quando afirma que "Nietzsche converte as condições de possibilidade kantianas em condições de vida" (RICHARDSON, 2013, p. 293). Sem dúvida, tais termos aparecem em muitos lugares na obra nietzschiana. Richardson lista uma série de aforismos nos quais tal expressão ou termos correlatos são encontrados, afirmando ainda que o uso desses termos nas obras publicadas é apenas a "ponta do iceberg" do grande número de ocorrências nos póstumos, existindo, por exemplo, mais de cinquenta ocorrências das expressões Existenz-Bedingung ou Existenzbedingung no KSA volumes 9-13" (RICHARDSON, 2013, p. 293, ver nota 5). Contudo, me parece que compreender tais expressões em termos biológicos, ou nas palavras de Richardson, em "termos darwinistas em um sentido amplo" (RICHARDSON, 2013, p. 295), perde de vista o âmago da crítica nietzschiana. Para essa discussão o aforismo 354 de A Gaia Ciência se mostra especialmente interessante:

(...) posso apresentar a conjectura de que a consciência se desenvolveu apenas sob a pressão da necessidade de comunicação - de que desde o início foi necessária e útil apenas entre uma pessoa e outra (entre a que comanda e a que obedece, em especial), e também se desenvolveu apenas em proporção ao grau dessa utilidade. Consciência é, na realidade, apenas uma rede de ligação entre as pessoas. (...) o pensar que se torna consciente é apenas a parte menor, a mais superficial, a pior digamos: - pois apenas esse pensar consciente ocorre em palavras, ou seja, em signos de comunicação, com o que se revela a origem da própria consciência. (...) Acrescente-se que não só a linguagem serve de ponte entre um ser humano e outro, mas também o olhar, o toque, o gesto; o tomar-consciência das impressões de nossos sentidos em nós, a capacidade de fixá-las e como que situá-las fora de nós, cresceu na medida em que aumentou a necessidade de transmiti-las a outros por meio de signos. (...) Meu pensamento, como se vê, é que a consciência não faz parte realmente da existência individual do ser humano, mas antes daquilo que nele é natureza comunitária e gregária; que, em consequência, apenas em ligação com a utilidade comunitária e gregária (...) Este é o verdadeiro fenomenalismo e perspectivismo, como eu o entendo: a natureza da consciência animal ocasiona que o mundo de que podemos nos tornar conscientes seja só um mundo generalizado, vulgarizado, - (...) que a todo tornar-se consciente está relacionada uma grande, radical corrupção, falsificação, superficialização e generalização (...) (NIETZSCHE, 2001, p. 247-250).

Esse aforismo defende que a linguagem e a consciência, o que tradicionalmente foi considerado como as características mais marcantes dos seres humanos, se desenvolveram como consequência da necessidade de comunicação e a utilidade para esse animal de "natureza social" que somos. Em outras palavras, Nietzsche defende que os seres humanos precisaram desenvolver algumas habilidades específicas para viver juntos, a linguagem e a consciência, que permitisse um tipo especial de comunicação necessário para sua sobrevivência. E mais, que esse tipo de comunicação só se tornou possível na medida em que linguagem e cons- 
ciência possibilitam uma compreensão comum e compartilhada do mundo, que é sempre limitada, e, para Nietzsche, portanto, um mundo "generalizado e vulgarizado". Esse mundo compartilhado e limitado é o que permite que seres humanos convivam, tornando possível não apenas a comunicação verbal, mas igualmente a compreensão de olhares, toques, gestos e signos diversos. Essa versão falsificada é fixada externamente e é compartilhada a partir de signos significativos, que localizam nossa "representação do mundo" fora de nós. Neste sentido, poderíamos afirmar que para Nietzsche, nossa relação com as coisas e com os outros (e ainda com nós mesmos) é derivada da fixação comum de um mundo simplificado, compartilhado e generalizado que guia e permite nossas percepções, nosso falar e consciência, na medida em que ela não é mais que uma "rede de ligação entre pessoas".

Ainda podemos ir além e sugerir que Nietzsche deseja, neste aforismo, se opor ao fenomenalismo naturalista de seus contemporâneos e apresentar sua própria posição ${ }^{15}$. Isto é, que nesse aforismo ele tenta deixar claro que não adere completamente ao projeto de naturalização da estrutura transcendental em termos de mero desenvolvimento biológicos e fisiológicos do ser humano (NIETZSCHE, 2005, \$15). Ao contrário, o "fenomenalismo e perspectivismo" nietzschiano assumiriam as condições transcendentais como a fixação de uma versão de mundo compartilhada, limitada por uma certa conceptualização que se desenvolve com e a partir da consciência e da linguagem. Desta maneira, ele assumiria que não apenas nossos órgãos biológicos e estrutura fisiológica são responsáveis pela maneira como nós percebemos e compreendemos o mundo, mas, ao contrário, subsiste uma origem "sócio-cultural" que fixa um mundo generalizado fora de nós e que funciona como uma espécie de condições transcendentais para a nossa relação com os fenômenos.

Ao mesmo tempo, ainda que exista uma divergência qualitativa em relação à versão naturalista de fenomenalismo, sua versão é fortemente marcada por se orientar, como Han-Pile chama à atenção, em "termos empíricos". De fato, esse mundo compartilhado, assim como a linguagem e a consciência na "conjectura" nietzschiana, se desenvolveram devido à necessidade de comunicação e sua utilidade para a espécie humana. Neste sentido, a tese de Richardson de que a filosofia nietzschiana pode ser lida em termos darwinistas em um sentido amplo parece não poder ser descartada, na medida em que o desenvolvimento de um mundo externo-falsificado-compartilhado é uma condição de vida-sobrevivência para os seres humanos. Em outras palavras, parece que aqui Nietzsche defende que cultura, linguagem e compreensibilidade se tornaram possíveis devido à sua utilidade na história de desenvolvimento-mutação-evolução do animal humano. No entanto, o aforismo não termina aí, ele continua desta maneira:

Não é, como se nota, a oposição entre sujeito e objeto que aqui me interessa: essa distinção
deixo para os teóricos do conhecimento que se enredam nas malhas da gramática (a me-
tafísica do povo). E menos ainda é a oposição entre fenômeno e coisa em si: pois estamos
longe de "conhecer" o suficiente para poder assim separar. Não temos nenhum órgão para
o conhecer, para a "verdade": nós "sabemos (ou cremos, ou imaginamos) exatamente tanto
quanto pode ser útil ao interesse da grege ${ }^{16}$ humana, da espécie: e mesmo o que aqui se
chama "utilidade" é, afinal, apenas uma crença, uma imaginação e, talvez, precisamente a
fatídica estupidez da qual um dia pereceremos. (NIETZSCHE, 2001, p. 250).

Esta última parte do aforismo pode parecer estranha à primeira vista, no entanto, é decisiva para a presente discussão. Primeiramente, Nietzsche afirma que assumir os limites e condicionamentos no conhecimento humano não tem nada a ver com a oposição entre sujeito e objeto e seus problemas. Essa distinção seria um problema para os teóricos da epistemologia e emerge das "malhas da gramática" (a metafísica do povo!). A crítica de Nietzsche à “fé na gramática” (NIETZSCHE, 2005, \$17 e \$34) é bem conhecida e ampla-

15 Eu agradeço a Renan Cortez pela longa discussão especificamente sobre esse aforismo. Sobretudo, devo a ele a ideia, que defendo no parágrafo, de que Nietzsche deseja demarcar e evidenciar a distinção em relação ao projeto de naturalização do transcendental e a sua posição quando formula a frase: "Este é o verdadeiro fenomenalismo e perspectivismo, como $\mathrm{eu} \mathrm{o}$ entendo" [o grifo do pronome pessoal na primeira pessoa é do próprio Nietzsche e não deve passar despercebido].

16 Termo latino para denominar a natureza gregária do ser humano. O tradutor do texto mantém o termo na tradução em português, aqui reproduzida. 
mente discutida ${ }^{17}$, mas essa passagem nos ajuda a compreender o que essa afirmação pode, afinal, significar. Ela aponta, sobretudo, ao fato de que o problema epistemológico sobre a relação entre sujeito e objeto surge de uma consideração teórica que inicialmente assume uma distância entre eles. Contudo, essa distância é derivada de uma regra gramatical. Seria estranho que Nietzsche afirmasse que, provavelmente, o problema mais difícil e clássico da teoria do conhecimento da relação entre o objeto e o sujeito (cuja dificuldade Kant fez menção ao nomeá-la como o escândalo da filosofia: o fato de ninguém até ele ter resolvido completamente o problema) fosse derivado apenas de uma simples e tola fé na gramática, se ele não admitisse um lugar "ontológico" para a linguagem. Linguagem, neste contexto, portanto, aparece como o meio pelo qual nós fixamos e compartilhamos com os outros nossa compreensão de mundo, e nesse sentido, ela estabelece os limites e possibilidades de nosso 'mundo'.

Isso significa dizer que, a maneira como pensamos e percebemos a realidade vêm à tona através da linguagem. Essa posição parece clara no aforismo 20 de Além do Bem e do Mal, quando Nietzsche defende que o surgimento das ideias filosóficas não é espontâneo, nem arbitrário, mas tampouco resultado de uma crítica radical dos pensadores anteriores. Ao contrário, ele defende que as ideias filosóficas surgem e se desenvolvem no interior e a partir de um "certo esquema básico de filosofias possíveis" (NIETZSCHE, 2005, p. 24). Esse esquema básico comum funcionaria como o horizonte que determina o que é possível ser pensado, do mesmo modo em que, por outro lado, interditaria o caminho para "certas possibilidades outras de interpretação do mundo" (NIETZSCHE, 2005, p. 24). É quase irresistível reconhecer nessa fala uma certa similaridade com a noção de "primeiro início" no pensamento tardio de Heidegger, com a qual ele reconhece que a história da compreensão de ser do Ocidente se realiza no interior de certos limites abertos pela tradição. Da mesma maneira, Nietzsche parece reconhecer que existe uma medida inicial que determina e limita nossas compreensões do mundo, atuando no interior da história da filosofia, de tal modo que os diversos sistemas mantêm uma espécie de familiaridade entre si. Em seguida, Nietzsche vai além e afirma que o desenvolvimento da história da filosofia, que se realiza no interior de determinadas possibilidades compreensivas, é diretamente determinado pelo tipo de linguagem que baliza nossa pré-compreensão do mundo. Esta é razão pela qual Nietzsche assume que, muito provavelmente, filósofos que falem línguas completamente distintas (que não possuam a mesma origem e estrutura que as línguas Indo-europeias) 'olharão 'para dentro do mundo' de maneira diversa e se acharão em trilhas diferentes" de pensamento (NIETZSCHE, 2005, p. 25), na medida em que seus pensamentos serão determinados por outras estruturas semânticas, outras "gramáticas". Ele vai além ao assumir que as limitações impostas pelas funções gramaticais que regem o pensamento de determinados povos são o "encanto de condições raciais e juízos de valor fisiológicos". (Idem). Os termos condições e juízos de valor nos remetem mais uma vez para as discussões ao redor de questões kantianas e neokantianas, mas o fazem de uma maneira curiosa, pois sugerem uma conexão entre restrições gramaticais, que possuem a capacidade de delimitar e orientar nossa compreensão de mundo, e a existência de diversos tipos de raças e tipos fisiológicos. Embora raça e fisiologia sejam termos biológicos, eles parecem nesse contexto subordinados à maneira pela qual nosso pensamento e compreensão do mundo são determinados. Como se tal pré-compreensão fosse responsável pela formação e desenvolvimento de tipos de vida distintos.

Neste sentido, podemos compreender que Nietzsche afirma que a gramática é a metafísica do povo porque ela funciona como um princípio condicionador de nossas possibilidades compreensivas compartilhadas. Isto é, ela estabelece a base a partir da qual acessamos e compreendemos os fenômenos, incluindo os outros e nós mesmos. Ao mesmo tempo, esse condicionamento não apenas delimita e orienta nossa maneira de pensar e filosofar, mas ainda, de maneira radical, nosso tipo de vida, isto é, permeia e perpassa todos os nossos comportamentos e modos de viver. Desta maneira, a expressão "fé na gramática" descreve criticamente o fato de que a linguagem exerce um poder normativo sobre os seus falantes, que não pode ser superado mesmo pelas mais rigorosas investigações filosóficas, pois esta possui suas possibilidades compreensivas delimitadas por aquela, na medida em que não podem prescindir dela para articular-se e projetar suas possibilidades.

17 Conferir, por exemplo, os debates amplamente conhecidos realizados por comentadores como Nehamas, A. (Nietzsche: Life as literature. Harvard University Press, 1985, p. 86 a 96) ou Schrift, A. (Nietzsche and the question of interpretation. Routledge, 1990) e a bibliografia aí sugerida. 
Essa afirmação possui, contudo, outra consequência, a saber, o fato de que descrever e investigar os limites de nosso próprio horizonte compreensivo é uma tarefa marcada por uma certa circularidade insuperável, uma vez que não podemos escapar completamente da pré-determinação a qual estamos circunscritos. A própria investigação destas condições é feita a partir e por meio da linguagem e não há formas de ultrapassarmos certos limites prévios que ela instaura. Nietzsche critica, desta maneira, o fato dos filósofos nem mesmo terem sido capazes de se dar conta de que boa parte de nossos problemas metafísicos surgiu e se desenvolveu por causa de determinadas abordagens teórico-linguísticas, presumindo que a maneira específica a partir da qual uma língua nomeia as coisas ou como descreve determinadas relações (a necessidade gramatical de atribuir um sujeito para toda ação, por exemplo, nas línguas indo-europeias) (NIETZSCHE, 2005, \$17 e \$34) expressem necessidades ontológicas. Mais ainda, pretendendo fundamentar tais necessidades ontologicamente, ao buscar sua origem em algum princípio a priori, para além das relações específicas da que surgem.

Poderíamos concluir, portanto, que a crítica nietzschiana diz respeito à clareza de que, ainda que existam estruturas condicionantes de nossa compreensão, jamais poderemos nos assegurar das mesmas ou dominá -las completamente, pois não podemos escapar delas para uma instância superior a fim de fundamentá-las. Nesse sentido, por mais que tenhamos estruturas que funcionem como fundamentos de nossas compreensões elas se mostram incapazes de serem fundamentadas e, por tanto, em última análise, infundadas. Esse seria a razão pela qual Nietzsche denomina nosso conhecimento ou mesmo as estruturas condicionantes de nossa compreensão de erro, pois não é possível garantir ou fundamentar sua verdade (de maneira universal, a priori etc) nos termos que a tradição pretendia e buscou fazê-lo. Mas, como vimos, no pensamento de Nietzsche, tais condicionantes ultrapassam em muito a constituição dos órgãos fisiológicos, as características físicas, psicológicas ou biológicas do ser humano. Ao contrário, elas dizem respeito à compreensibilidade do ser dos entes, que se dá por meio da fixação de um mundo compartilhado, que perpassa a linguagem, a consciência e a identificação dos entes, a partir de tradições abertas historicamente.

Neste sentido, podemos identificar na apropriação nietzschiana do retorno à filosofia de Kant, um aspecto que poderíamos aproximar da tradição hermenêutica, na medida em que aceita que horizontes históricos funcionam como condições de possibilidade de nossa relação compreensiva com o mundo, que, em última análise, perpassa também toda e qualquer possibilidade empírica e científica. Esse recuo hermenêutico poderia, contudo, ser considerado como uma radicalização da crítica da existência humana finita, com certas similaridades ao projeto heideggeriano expresso em seus textos da maturidade ${ }^{18}$.

\section{Considerações finais}

O presente texto espera ter apontado e discutido, a partir de uma reconstrução histórico-filosófica, a relação entre a filosofia e as ciências no século XIX. A partir de uma visão geral sobre o desenvolvimento das ciências naturais no período, se discutiu, com maior ênfase, o caso da Alemanha. Mostrou-se que alguns fatores como o desenvolvimento tardio das ciências naturais neste país, a forte tradição metafísica, o projeto de Universidade como instituição de pesquisa etc., permitiu que na Alemanha uma relação maior entre filosofia e ciências se estabelecesse. Essa conexão entre esses "tipos de saberes" não possui uma única matriz, mas, ao contrário, se deu a partir de tensões, encontros e oposições específicas a partir dos autores ou escolas que a problematizaram.

No entanto, podemos considerar que, como um todo, essa conexão estabeleceu uma reverberação recíproca de influência e importância entre ciências e filosofia, na medida em que estabeleceu muitas relações possíveis entre esses conhecimentos. Quer dizer, tanto a filosofia permeou os debates teóricos científicos, evidenciando como problemas de cunho filosófico sempre se reinscrevem em toda produção de conhecimento humano, quanto a consolidação das ciências trouxe desafios e questões específicas para a própria filosofia. No primeiro caso poderíamos citar como exemplo, o retorno a questões epistemológicas levadas a cabo por

18 Para uma discussão detida sobre essa questão ver meus textos: A herança transcendental na tradição hermenêutica: um debate sobre a radicalidade da finitude (2016, no prelo), Nietzsche and Hermeneutical thinking: Finitude and Truth (2016, no prelo) ou ainda, a segunda parte de minha tese: Verdade, finitude elugar: para uma hermenêutica topológica finita (2016, UERJ). 
cientistas, decorrente da crise no modelo positivista e na matriz da mecânica clássica. No segundo, a crise de legitimidade da filosofia como conhecimento a partir da decadência da metafísica, simbolizada pela morte de Hegel e de seu sistema, amplamente difundido, na filosofia alemã e do desenvolvimento das conquistas das ciências naturais.

Vimos ainda que, a filosofia kantiana desempenhou um papel fundamental nesse período para tais discussões, de forma tão relevante que muitos comentadores aceitam que ocorreu, na segunda metade do século XIX, um "retorno a Kant". Kant, portanto, precisa ser destacado como uma figura central deste debate profícuo e conflitante entre ciências e filosofia no séc. XIX, apesar de ter servido a apropriações diversas tais como: o projeto de naturalização do transcendental, levado a cabo, sobretudo, por cientistas, mas também por autores como Lange; a defesa da redução do papel da filosofia à epistemologia ou o retorno à primazia da filosofia prática, realizadas pelas chamadas escolas neokantianas; a fenomenologia husserliana como crítica filosofia transcendental científica; os projetos hermenêuticos de ampliação do projeto de crítica kantiana da finitude da razão para a finitude da existência, considerando a historicidade da vida humana como condições de possibilidade de sua existência compreensiva-interpretativa, em autores como Dilthey, Nietzsche e Heidegger, apesar das diferenças relevantes e insuperáveis de seus projetos; entre outros exemplos de autores e correntes.

\section{Referências bibliográficas}

BASTOS, Maria Helena Câmara. A educação comparada no século XIX: A obra de Célestin Hippeau. Texto apresentando no Encontro Internacional: Construindo a Identidade Latino-Americana (De 10 a 12 de novembro de 2003), PUCRS, Porto Alegre, RS. Disponível em http://www.sbec.org.br/evt 2003.php em 10 de agosto de 2012.

CASSIRER, Ernst. Substance and Function \& Einstein's Theory of Relativity. Dover Publications Inc., 1953.

COMTE, Auguste. Curso de filosofia Positiva. Tradução: José Arthur Giannotti. São Paulo: Abril Cultural, 1978. (Coleção Os Pensadores)

DILTHEY, Wilhelm. A construção do mundo histórico nas ciências humanas. Tradução: Marco Antônio Casanova. São Paulo: Editora UNESP, 2010. rita, 2011.

Ideias sobre uma psicologia descritiva e analítica. Tradução: Marco Antônio Casanova. Rio de Janeiro: Via Ve-

DUARTE, André. Heidegger e a possibilidade de uma antropologia existencial. Natureza humana, São Paulo, v. 6, n. 1, p. 29-51, jun. 2004.

GALILEU. O ensaiador. Tradução: Helda Barraco. São Paulo: Abril Cultural, 1978. (Coleção Os Pensadores).

GORDON, Peter. Continental Divide: Heidegger, Cassirer, Davos. Cambridge, Harvard University Press, 2012.

GREEN, Michael. Nietzsche and the Transcendental Tradition. Urbana and Chicago: University of Illinois Press, 2002.

HAN-PILE, Béatrice. “Transcendental Aspects, Ontological Commitments and Naturalistic Elements in Nietzsche's Thought". In: Inquiry: An Interdisciplinary Journal of Philosophy, 52:2, pp. 179-214. DOI:10.1080/00201740902790243, 2009.

HEIDEGGER, M. The Basic Problems of Phenomenology. Trad. ao inglês de Albert Hofstadter. Bloomington \& Indianapolis: Indiana University Press, 1982.

Os conceitos fundamentais da Metafísica: mundo, finitude, solidão. Tradução: Marco Antonio Casanova. Rio de Janeiro: Forense Universitária, 2006.

Kant and the problem of metaphysics. Tradução para o inglês de Richard Taft. Bloomington \& Indianapolis: Indiana University Press, 1997b.

Nietzsche I e Nietzsche II. Tradução de Marco Antônio Casanova. Rio de Janeiro: Forense Universitária, 2007.

Ontologia (Hermenêutica da facticidade). Trad. Renato Kirchner. Petrópolis: Editora Vozes, 2012.

Ser e tempo. Parte I e parte II. Trad. Marcia Cavalcante Schuback. Petrópolis: Editora Vozes, 2005. 
HUSSAIN, Nadeem. "Nietzsche's Positivism”. In: European Journal of Philosophy, vol.12, n.3, Oxford: Blackwell Publishing Ltd., pp. 326-368.

HUSSERL, Edmund. Logical Investigations. Ed. Dermot Moran. 2nd ed. 2 vols. London: Routledge, 2001.

KANT, Immanuel. Crítica da Razão Pura. (6 ed). Trad. Manuela dos Santos e Carlos Morujão. Lisboa: Fundação Calouste Gulbenkian, 2008.

LANGE, F. A. Historia del materialismo [Geschichte des Materialismus und Kritik seiner Bedeutung in der Gegenwart, 1866], tomo II, Trad. ao espanhol de Vicente Colorado. Madrid: Daniel Jorro Ed., 1903.

LOPES, Rogério Antônio. Ceticismo e vida contemplativa em Nietzsche. 2008. 573 f. Tese (Doutorado em Filosofia). Universidade Federal de Minas Gerais, Minas Gerais, 2008.

LÖWITH, Karl. De Hegel a Nietzsche: La quiebra revolucionaria del pensamiento em el siglo XIX. Tradução ao espanhol de Emilio Estiú. Buenos Aires: Katz editores, 2012.

MAKREEL, Rudolf A.; RODI, Frithjof. “Introduction to volume III”. In: Wilhelm Dilthey: Selected Works, Volume III: The Formation of the Historical World in the Human Sciences. Princeton: Princeton University Press, 1991.

MERZ, John Theodore. A history of European thought in the nineteenth century. Vol. I. London: Willian Blackhood and sons, 1907.

MOREIRA, Ildeu de Castro. As visões física e epistemológica de Hertz e suas repercussões. In: Revista da SBHC, n. 13, p. 53-64, 1995.

NIETZSCHE, F. Além do Bem e do Mal: prelúdio a uma filosofia do futuro. Trad. Paulo César de Souza. São Paulo: Companhia das Letras, 2005.

. A Gaia Ciência. Trad. Paulo César de Souza. São Paulo: Companhia das Letras, 2001.

. Genealogia da Moral: Uma polêmica. Trad. Paulo César de Souza. São Paulo: Companhia das Letras, 1998.

POPPER, Karl. A Lógica da Investigação Científica. Trad. Pablo Rubén Mariconda. São Paulo: Abril Cultural, 1980. (Coleção Os Pensadores).

RICHARDSON, John. 'Nietzsche and transcendental argument'. In: Kriterion, Belo Horizonte, no 128, Dez, pp. $287-$ $305,2013$.

SCHNÄDELBACH, Herbert. Filosofía em Alemania (1831-1933). Tradução Espanhol: Pepa Linares. Madrid: Ediciones Cátedra, 1991.

SOUZA FILHO, Osvaldo Melo. A física de Helmholtz e suas bases filosóficas. In: Revista da SBHC, n. 13, p. 53-64, 1995.

STACK, George J. 'Kant, Lange, and Nietzsche: critique of knowledge’. In: Ansell-Pearson, Keith (Ed). Nietzsche and Modern German Thought, pp.30-58. London and New York: Routledge, 1991.

. Lange and Nietzsche. Berlin; New York: de Gruyter, 1983.

VIDEIRA, Antonio Augusto P. Boltzmann, física teórica e representação. Revista Brasileira de Ensino de Física, v. 28, n. 3, p. 269-280, 2006.

. A inevitabilidade da filosofia na ciência natural do século 19: o caso da física teórica. Ijuí: Editora Unijuí, 2013.

. Metafísica, Físicos, Valores: Um ensaio sobre a crise dos fundamentos das ciências naturais na passagem do século XIX para o século XX. In: Ensaios Filosóficos, Volume IV, p. 186-214, outubro/2011.

VIDEIRA, Antonio Augusto P; COELHO, Ricardo L (org.). Física, mecânica e filosofia: o legado de Hertz, tradução: Gabriel Dirma Leão. Rio de Janeiro: EdUERJ, 2012.Resumo 